\title{
Supramolecular imaging agents targeting cancer biomarkers
}

\author{
Faustine d'Orchymont and Jason P. Holland*
}

University of Zurich, Department of Chemistry, Winterthurerstrasse 190, CH-8057, Zurich,

Switzerland

* Corresponding Author:

Prof. Dr Jason P. Holland

ORCID: orcid.org/0000-0002-0066-219X

Tel: +41-44-63-53990

E-mail: jason.holland@.chem.uzh.ch

Website: www.hollandlab.org

Twitter: @HollandLab_

First Author:

Dr Faustine d'Orchymont

ORCID: orcid.org/0000-0002-3726-1648

E-mail: faustine.dOrchymont@.chem.uzh.ch 


\begin{abstract}
Mechanically interlocked molecules present opportunities to construct therapeutic drugs and diagnostic imaging agents but harnessing supramolecular chemistry to make biologically active molecules in water is a challenge. Here, we describe a rotaxane-based approach in the synthesis of radiolabelled proteins and peptides for molecular imaging of cancer-specific biomarkers in vivo. Host-guest chemistry with mono-functionalised $\beta$-cyclodextrin, combined with curcurbit[6]uril catalysed cooperative capture synthesis, produced radioactive gallium-68 or zirconium-89labelled metallo[4]rotaxanes. Simultaneous, one-pot radiolabelling and photochemical conjugation to monoclonal antibodies produced a viable radiotracer that was evaluated in vivo for quantitative positron emission tomography (PET) imaging of cancer biomarker expression. The rotaxane architecture can be easily tuned to accommodate different radioactive metal ion complexes, other proteins and peptide-based drugs, and fluorophores for optical detection. This technology provides a future platform to explore the use of mechanical bonding to optimise drug delivery, control metabolism and excretion profiles, and enhance the efficacy of tumour specific agents.
\end{abstract}




\section{INTRODUCTION}

Linking molecules together through non-covalent, mechanical bonds can impart unique physical and chemical features to these supramolecular systems that would be difficult, or even impossible, to achieve through classic synthetic methodology. ${ }^{1,2}$ The ability to control the shape and dynamic motion of mechanically interlocked molecules (MIMs) by the use of external stimuli has made headlines with the construction of artificial molecular machines. ${ }^{3-6}$ Functional $^{7}$ supramolecular compounds have also been used in many applications ranging from logic gates or molecular switches for electronic devices, ${ }^{8}$ as molecular nanovalves for controlling drug release from nanoporous materials, ${ }^{9}$ and as catalysts. ${ }^{10,11}$

In a biomedical context, supramolecular coordination complexes show promise in several applications $^{12,13}$ from cytotoxic ${ }^{14-16}$ and drug delivery ${ }^{17-19}$ through to biosensors for DNA recognition, ${ }^{20}$ and reporter probes for diagnostic molecular imaging. ${ }^{12}$ For example, rotaxanes loaded with cytotoxic $\mathrm{Pt}^{14}$ or $\mathrm{Ru}^{16}$ complexes, and other systems capable of selective $\mathrm{Ca}^{2+}$ ion binding, ${ }^{15}$ have displayed antitumour properties against human cancer cells. Rotaxanes have also been engineered with sophisticated drug-release mechanisms ${ }^{21,22}$ that feature enzyme-mediated disassembly of a prodrug inside tumour cells via multiple cleavage steps that separate a stabilising macrocycle from a cytotoxic drug-capped axle. ${ }^{18}$

Relatively few examples exist where supramolecular chemistry was employed in the design of molecular imaging agents. Lusby, Archibald and co-workers reported the successfully radiosynthesis of a supramolecular complex by encapsulating the $\gamma$-ray emitting $\left[{ }^{99 \mathrm{~m}} \mathrm{Tc}\right] \mathrm{TcO}_{4}{ }^{-}$ pertechnetate anion inside the cavity of a tetrahedral $\mathrm{Co}(\mathrm{III})_{4} \mathrm{~L}_{6}$-metallocage, where $\mathrm{L}$ is a terpyridine-based ligand, for applications in single-photon emission computed tomography

(SPECT) imaging (Figure 1). ${ }^{23}$ In vivo imaging showed that the ${ }^{99 \mathrm{~m}} \mathrm{Tc} \supset \mathrm{metallocage}$ complex had 
a different pharmacokinetic profile compared with free pertechnetate, confirming that the radiolabelled metallocage was stable in a complex biological environment, and that the encapsulation strategy is a potential platform for developing target-specific radiotracers. In a major step toward targeted supramolecular radiotracers, Casini and co-workers demonstrated that the exterior of a $\left[\mathrm{Pd}_{2} \mathrm{~L}_{4}\right]^{4+}$ metallocage, where $\mathrm{L}=3,5$-bis(3-ethynylpyridine)phenyl ligand, can be modified with a blood-brain-barrier translocating peptide for potential brain-targeted delivery and SPECT imaging with the encapsulated $\left[{ }^{99 \mathrm{~m}} \mathrm{Tc}_{\mathrm{TcO}}{ }^{-}\right.$anion (Figure 1). ${ }^{24}$ Supramolecular techniques have also been used to design fluorescent probes for applications in optical imaging. ${ }^{25}$ Smith and co-workers recently used their optically active squaraine-dye-rotaxane system ${ }^{26}$ to create a interlocked, figure-of-eight molecular knot (Figure 1). ${ }^{27}$ They incorporated cell binding peptide sequences to link the axle termini to a bifunctional macrocycle via $\mathrm{Cu}(\mathrm{I})$ azide-alkyne click chemistry. The stability and peptide-knot topology combined with the high brightness of the squaraine-dye shows promise for developing new probes for fluorescence microscopy and biomedical imaging. Hasenknopf and co-workers have also developed optically active polyrotaxanes for fluorescence imaging, ${ }^{28}$ and $\mathrm{Gd}^{3+}$-labelled [3] rotaxanes as highly effective magnetic resonance imaging (MRI) contrast agents. ${ }^{29}$ In spite of their potential, targeted imaging of cancer-specific biomarkers with a rotaxane, metallocage, or catenane architecture has remained elusive.

Adapting self-assembly mechanisms to operate in water is a fundamental barrier to using supramolecular chemistry in biological applications. ${ }^{30}$ Encouragingly, Bruns et al. ${ }^{31}$ reported the near quantitative synthesis of rotaxanes via bioconjugation to peptides and proteins. Here, we report the development of a rotaxane-based approach to create radiolabelled, and optically active, imaging agents that can be easily conjugated to cancer-targeted monoclonal antibodies or peptidic- 
drug molecules. Our design strategy builds on the multiple-component cooperative capture synthesis methods from Stoddart and co-workers (Figure 1). ${ }^{32-34}$ The introduction of monofunctionalised $\beta$-cyclodextrin units, combined with either symmetric or unsymmetrical axle capping provides up to three positions for selectively combining radiometal ion complexes and optically active species, with biologically active vectors (Figure 1).

\section{Insert_Figure_1}

\section{RESULTS AND DISCUSSION}

\section{Cooperative capture synthesis of radiolabelled rotaxanes}

In developing our cancer-targeted supramolecular radiotracers, we first defined the design criteria. The supramolecular methodology should ideally feature rapid self-assembly and generate a molecule with flexible topology. The compound should have a well-defined stoichiometry that allows for the facile rearrangement or replacement of the different components. The supramolecule should be biocompatible, soluble in water, and stable under the conditions used to label proteins or peptides. For radiotracer synthesis, the probe must be easily purified, and should be chemically and metabolically stable under physiologically relevant conditions. Finally, the imaging probe should display specificity both in vitro and in vivo for the biomarker of interest and provide lesionspecific accumulation with high image contrast. Taking these points into consideration, cooperative capture synthesis fulfils many of these criteria. ${ }^{32-34}$

In 1983, Mock and $\mathrm{Shih}^{35}$ reported that 1,3-dipolar cycloaddition reactions between aliphatic azides and terminal alkynes can be accelerated by encapsulation of the reagents inside the macrocyclic cavity of curcurbit[6]uril, $\mathrm{CB}[6]$. The reaction proceeds in accordance with the Pauling principle of catalysis whereby the rate of triazole formation in the presence of $\mathrm{CB}[6]$ 
increased by a factor of $5.5 \times 10^{4} \cdot{ }^{36} \mathrm{CB}[6]$-promoted click chemistry was later used to make polyrotaxanes,${ }^{37}$ discrete hetero[n]rotaxanes, ${ }^{32-34}$ and protein conjugates. ${ }^{38}$ Stoddart and coworkers also discovered that the addition of $\beta$ - or $\gamma$-cyclodextrin (CD), or pillar[n]arene macrocycles to the one-pot, multi-component reaction can increase rates further due to macrocyclic preorganisation via intermolecular hydrogen-bonding. ${ }^{34}$

Prior to developing a cancer-targeted supramolecular radiotracer, we tested the use of cooperative capture synthesis to make a radiolabelled rotaxane (Figure 2; see also Supplementary Schemes S1-S3, Figures S1-S45 and Table S1 for additional characterisation data). The multicomponent reaction involves the addition of one equivalent of biphenyl-dialkyne guest $\mathbf{1}$ with one equivalent of non-functionalised $\beta-\mathrm{CD}$ to form an initial molecular inclusion complex $(1 \supset \beta-\mathrm{CD}$, Figure 2b, Supplementary Figures S4-S9). Then, two equivalents of both CB[6] and DFO-azido 2, a novel derivative of the acyclic metal ion binding chelate desferrioxamine B (DFO) with 1-(2azidoethyl)piperidine-4-carboxylic acid, are added and the reaction was heated at $70{ }^{\circ} \mathrm{C}$ for 1 minute in water. After purification of the crude reaction mixture by using semi-preparative highperformance liquid chromatography (HPLC), [4]pseudorotaxane 3 was isolated in 56\% yield. Compound $\mathbf{3}$ was characterised by analytical HPLC, electrospray ionisation high-resolution mass spectrometry (HRMS ESI), 1-dimensional and 2-dimensional ${ }^{1} \mathrm{H}$ - and ${ }^{13} \mathrm{C}\left\{{ }^{1} \mathrm{H}\right\}$-NMR spectroscopy methods (Supplementary Figures S30-S39). Hydrogen bonding interactions between the CB[6] and $\beta$-CD rings restricts the conformational flexibility of the [4]pseudorotaxane 3 with the result that the aromatic proton environments of the encapsulated biphenyl unit become magnetically inequivalent (Figure 2b). Metal ion complexation with ${ }^{\text {nat }} \mathrm{Ga}\left(\mathrm{NO}_{3}\right)_{3}$ or ${ }^{\text {nat }} \mathrm{ZrCl}_{4}$ (Supplementary Figures S40-S43) produced the metallo[4]rotaxanes ${ }^{\text {nat }} \mathrm{Ga}-3$ or ${ }^{\text {nat }} \mathrm{Zr}-\mathbf{3}$ capped at both ends of the axle by the respective ${ }^{\text {nat }} \mathrm{Ga}^{3+}$ or ${ }^{\text {nat }} \mathrm{Zr}^{4+} \mathrm{DFO}$ complexes. 
The equivalent radioactive metal ion complexes were synthesised by using stock solutions of $\left[{ }^{68} \mathrm{Ga}\right] \mathrm{GaCl}_{3}$ (aq.) $\left(t_{1 / 2}=67.7 \mathrm{~min}\right)$ or $\left[{ }^{89} \mathrm{Zr}\right]\left[\mathrm{Zr}\left(\mathrm{C}_{2} \mathrm{O}_{4}\right)_{4}\right]^{4-}$ (aq.) (also called ${ }^{89} \mathrm{Zr}$-oxalate, $t_{1 / 2}=78.41$ h). To the best of our knowledge, $\left[{ }^{68} \mathrm{Ga}\right] \mathrm{Ga}-3$ and $\left[{ }^{89} \mathrm{Zr}\right] \mathrm{Zr}-3$ are the first examples of radiolabelled rotaxanes. The radioactive products were characterised by analytical radioactive thin-layer chromatography (radio-TLC; Figure 2c) and radio-HPLC (Figure 2d). Both $\left[{ }^{68} \mathrm{Ga}\right] \mathrm{Ga}-\mathbf{3}$ and $\left.{ }^{[89} \mathrm{Zr}\right] \mathrm{Zr}-3$ were retained at the baseline (retention factor, $R_{\mathrm{f}}=0.0-0.1$ ), whereas control reactions in the absence of $\mathbf{3}$ showed the migration of the activity, present as either $\left[{ }^{68} \mathrm{Ga}\right]\left[\mathrm{Ga}(\text { citrate })_{2}\right]^{3-}$ or $\left[{ }^{89} \mathrm{Zr}\right][\mathrm{Zr}(\mathrm{DTPA})]^{-}$to the solvent front $\left(R_{\mathrm{f}}=0.9-1.0\right)$. Comparison of the radio-HPLC retention times of $\left[{ }^{68} \mathrm{Ga}\right] \mathrm{Ga}-3$ or $\left[{ }^{89} \mathrm{Zr}\right] \mathrm{Zr}-3$ species with chromatograms of the authenticated non-radioactive samples (measured at $254 \mathrm{~nm}$ ) confirmed product identities. Both ${ }^{68} \mathrm{Ga}$ - and ${ }^{89} \mathrm{Zr}$-radiolabelling reactions gave a decay-corrected radiochemical yield (RCY) of $>98 \%$, and integration of the radioHPLC chromatograms confirmed that $\left[{ }^{68} \mathrm{Ga}\right] \mathrm{Ga}-3$ and $\left[{ }^{89} \mathrm{Zr}\right] \mathrm{Zr}-3$ were obtained with a radiochemical purity $(\mathrm{RCP})$ of $>95 \%$ and $>90 \%$, respectively.

To develop a targeted supramolecular radiotracer, the mechanical bond must be stable toward disassembly. Stability tests in water confirmed that metallation and axle-capping with either ${ }^{\text {nat }} \mathrm{Ga}^{3+}$ or ${ }^{\text {nat }} \mathrm{Zr}^{4+}$ ions prevented dethreading of the macrocycles (Figure 2e and Supplementary Figure S44). The metallo[4]rotaxanes were stable for over $96 \mathrm{~h}$, whereas [4]pseudorotaxane 3 dissociated under the same conditions. Remarkably, HPLC analysis of a lyophilised sample of nat $\mathrm{Ga}-3$ after 3-years under ambient conditions $\left(23-30^{\circ} \mathrm{C}\right.$, transparent glass vial) showed no degradation (Supplementary Figure S45).

Density functional theory (DFT) calculations were also used to optimise the ground-state geometry of a model of [4]pseudorotaxane $3 .{ }^{39}$ The structure revealed a distinct curvature of the axle which bends to accommodate the three macrocyclic rings. The larger surface area and 
increased number of hydrogen bond donor groups on the 2,3-face of $\beta$-CD allows for closer contact with $\mathrm{CB}[6]$ than on the narrower 6-face. This molecular asymmetry, and the increased rigidity of the system, is the origin of splitting observed for the biphenyl protons in the ${ }^{1} \mathrm{H}-\mathrm{NMR}$ spectrum of 3 (Figure 2b). The rotaxane also displays planar chirality, a phenomenon which has been explored in detail by Goldup and co-workers and generates isomers. ${ }^{2,11}$

\section{Insert_Figure2}

\section{Synthesis and characterisation of a ${ }^{89} \mathrm{Zr}$-radiolabelled rotaxane-antibody for PET}

Next, we synthesised a cancer-targeted rotaxane by installing a photochemically active aryl azide $\left(\mathrm{ArN}_{3}\right)$ onto the $\beta$-CD to create the [4]pseudorotaxane 5, and then performed the one-pot (simultaneous) ${ }^{89} \mathrm{Zr}$-radiolabelling and light-induced protein ligation ${ }^{40}$ to trastuzumab - a monoclonal antibody (mAb) that binds an extracellular epitope of the human epidermal growthfactor receptor 2 (HER2/neu). ${ }^{41,42}$ Details on the synthesis, radiochemistry and characterisation of $\left[{ }^{89} \mathrm{Zr}\right] \mathrm{ZrFe}-[4]$ rotaxane-trastuzumab, $\left[{ }^{89} \mathrm{Zr}\right] \mathrm{ZrFe}-\mathbf{6}$, are presented in Figure 3 (see also Supplementary Scheme S4, Figures S46-S89 and Tables S2-S4).

In a 6-step procedure, $\beta$-CD was mono-functionalised at one of the 6-hydroxyl positions to give the photoactivatable derivative $\beta-\mathrm{CD}-\mathrm{ArN}_{3}$ (4; Supplementary Scheme $\mathrm{S4}$ and Figures S46-S62). Cooperative capture synthesis gave [4]pseudorotaxane 5 in 54\% yield after purification, which was characterised by HPLC, HRMS, and multinuclear NMR spectroscopy (Supplementary Figures S63-S69). Metallation of 5 with ${ }^{\text {nat }} \mathrm{Ga}^{3+}$ gave metallo[4]rotaxane ${ }^{\text {nat }}$ Ga-5, which was characterised and found to be stable in water for over 96 h (Supplementary Figures S70-S72). When 5 or nat Ga-5 was irradiated with a light-emitting diode (LED, $395 \mathrm{~nm}$ ), rapid photochemical degradation was observed by analytical HPLC (Figure 3b, black curve, and Supplementary 
Figure S73). As a control, ${ }^{\text {nat }} \mathrm{Ga}-3$ which contains non-functionalised $\beta-\mathrm{CD}$, was stable toward irradiation (Figure 3, purple curve). Interestingly, metallation of 5 with ${ }^{\text {nat }} \mathrm{Zr}^{4+}$ ions produced the desired metallo[5]rotaxane, natZr-5, where at least three isomers (confirmed by HRMS) with distinct retention times were observed in the analytical HPLC chromatogram (Supplementary Figures S75-S79). Complexation of $\mathrm{Zr}^{4+}$ ions by DFO results in multiple geometric and stereochemical isomers in which solvent coordination can also expand coordination numbers from 6 to $8 .{ }^{43}$ Planar chirality ${ }^{211}$ of the rotaxane increases further the number of possible isomers which accounts for the observed profile in the analytical HPLC chromatogram of ${ }^{\text {nat }} \mathrm{Zr-5}$.

Starting from an initial 2:1 mole ratio of [4]pseudorotaxane 5 to $\mathrm{mAb},{ }^{89} \mathrm{Zr}$-radiolabelling of 5 and light-induced conjugation to trastuzumab, followed by reaction quenching with $\mathrm{FeCl}_{3}$ and DTPA in situ gave the rotaxane-mAb conjugate, $\left[{ }^{89} \mathrm{Zr}\right] \mathrm{ZrFe}-6$. Aliquots of the crude reaction were retained for analysis and $\left[{ }^{89} \mathrm{Zr}\right] \mathrm{ZrFe}-6$ was purified by manual size-exclusion chromatography (SEC) by using Sephadex G-100 gel filtration columns. The $\left[{ }^{89} \mathrm{Zr}\right] \mathrm{ZrFe}-6$ product was isolated in sterile PBS (pH7.4) with a decay-corrected RCY of $14.0 \pm 5.0 \%(n=3)$, an average RCP of $91 \pm 2 \%$ (measured by radio-SEC-HPLC), and a molar activity $A_{\mathrm{m}}$ of $0.604-0.671 \mathrm{MBq} \mathrm{nmol}{ }^{-1}$ of protein. $\left[{ }^{89} \mathrm{Zr}\right] \mathrm{ZrFe}-6$ was characterised by radio-TLC and analytical size-exclusion chromatography (SEC) coupled to a HPLC (Figures 3c and 3d, and Supplementary Figures S80-S81). Radio-TLC analysis confirmed that quantitative radiochemical conversion occurred to give the intermediate semi[4]rotaxane $\left.{ }^{89} \mathrm{Zr}\right] \mathrm{Zr}-5$ (Figure 3c, green), and that no 'free' ${ }^{89} \mathrm{Zr}^{4+}$ ions were present in either the crude (blue) or purified (orange) samples of $\left[{ }^{89} \mathrm{Zr}\right] \mathrm{ZrFe}-6$. Analytical SEC-HPLC analysis with both electronic absorption and radioactivity detection confirmed that the ${ }^{89} \mathrm{Zr}$-activity eluted at the same point (peak $\sim 12.7 \mathrm{~mL}$; indicated by ' $\Delta$ ' Figure 3d, orange) as the trastuzumab protein peak measured at $280 \mathrm{~nm}$ (black). Comparison of chromatograms from the crude versus purified 
samples of $\left[{ }^{89} \mathrm{Zr}\right] \mathrm{ZrFe}-6$ confirmed the efficiency of the single-step purification process. The FeDFO complex shows a strong absorption band centred at $430 \mathrm{~nm}$, and the chromatogram of the purified sample, monitored at this wavelength (Figure 3d, red), confirmed that the radiolabelled rotaxane was capped by both ${ }^{89} \mathrm{Zr}^{4+}$ and $\mathrm{Fe}^{3+}$ ions.

Before testing $\left[{ }^{89} \mathrm{Zr}\right] \mathrm{ZrFe}-6$ in animals, cellular saturation binding experiments ${ }^{44}$ were performed to estimate the immunoreactive fraction by using SK-OV-3 human ovarian cancer cells in vitro. Binding experiments confirmed that $\left[{ }^{89} \mathrm{Zr}\right] \mathrm{ZrFe}-6$ was biologically active and displayed specific binding to HER2/neu with a measured immunoreactive fraction of $61 \pm 5 \%$ ( $n=3$; Figure 3e, Supplementary Figure S82).

The radiosynthesis of $\left[{ }^{89} \mathrm{Zr}\right] \mathrm{ZrFe}-6$ was scaled-up to obtain sufficient activity for smallanimal PET imaging and biodistribution studies in female athymic nude mice bearing subcutaneous SK-OV-3 xenografts on the right flank. Animals ( $n=5$ mice / group) were randomly assigned to two groups which received $\left[{ }^{89} \mathrm{Zr}\right] \mathrm{ZrFe}-6$ (in sterile PBS, pH7.4) as either a normal higher molar activity dose $\left(A_{\mathrm{m}}=0.604-0.671 \mathrm{MBq} \mathrm{nmol}^{-1}\right.$ of protein $)$ or a blocking dose that contained the same amount of activity but an increased mass of protein $\left(A_{\mathrm{m}}=0.020-0.021 \mathrm{MBq}\right.$ $\mathrm{nmol}^{-1}$ ). The blocking group is a standard control used to demonstrate the specific binding of $\left[{ }^{89} \mathrm{Zr}\right] \mathrm{ZrFe}-6$ in vivo, through modulation of the tumour uptake by saturating the available HER2/neu receptors. Tomographic PET image data (Figure 3f) as well as maximum intensity projects (MIPs; Supplementary Figures S83-S84) confirmed the high tumour uptake and specificity of $\left[{ }^{89} \mathrm{Zr}\right] \mathrm{ZrFe}-6$ for detecting HER2/neu-expression in SK-OV-3 xenografts. Quantitative volume-of-interest (VOI) analysis of the PET data versus time produced time-activity curves (TACs) for the normal and blocking groups (Figures 3g and 3f, and Supplementary Figure S85 and Table S2). PET data revealed tumour-specific uptake of $\left[{ }^{89} \mathrm{Zr}\right] \mathrm{ZrFe}-6$ in the normal group 
reached $9.99 \pm 3.48 \% \mathrm{ID} \mathrm{cm} \mathrm{cm}^{-3}$ (percentage injected dose per cubic centimetre) at $72 \mathrm{~h}$ postradiotracer injection. In comparison, tumour uptake of $\left[{ }^{89} \mathrm{Zr}\right] \mathrm{ZrFe}-6$ was reduced by $\sim 60 \%$ in the blocking group $\left(4.02 \pm 0.81 \% \mathrm{ID} \mathrm{cm} \mathrm{cm}^{-3}, P\right.$-value$\left.=0.0070\right)$. TAC data showed that, excluding the tumour, no difference was observed in the pharmacokinetic profile of $\left[{ }^{89} \mathrm{Zr}\right] \mathrm{ZrFe}-6$ in the two groups. Clearance of $\left[{ }^{89} \mathrm{Zr}\right] \mathrm{ZrFe}-6$ from the blood pool had a measured half-life of $8.75 \pm 1.64 \mathrm{~h}$ for the normal group and $9.34 \pm 2.67 \mathrm{~h}$ for the blocking group.

After the final imaging time point, animals were euthanised and biodistribution analysis was performed to quantify the radiotracer distribution across 15 tissues (Figure 3i, and Supplementary Figure S86 and Table S3). The biodistribution data corroborated the accuracy of the PET images, revealing a tumour-associated accumulation of $11.88 \pm 3.90 \% \mathrm{ID} \mathrm{g}^{-1}$ (percentage injected dose per gram) in the normal group and a reduction of $>70 \%$ in the blocking group $\left(3.51 \pm 1.12 \% \mathrm{ID} \mathrm{g}^{-1}, P\right.$-value $\left.=0.0068\right)$.

As an additional control, PET images and biodistribution data were also recorded for $\left[{ }^{89} \mathrm{Zr}\right] \mathrm{ZrFe}-[4]$ rotaxane-2-hydroxyazepin, which is the main small-molecule byproduct formed by hydrolysis of the ketenimine ${ }^{45}$ intermediate during the photoradiosynthesis (referred to as the 'metabolite' sample, Supplementary Figure S87-S88 and Table S4). ${ }^{46}$ Imaging data confirmed that $\left[{ }^{89} \mathrm{Zr}\right] \mathrm{ZrFe}-[4]$ rotaxane-2-hydroxyazepin was rapidly extracted from the blood pool and eliminated mainly via renal excretion. Measurements of the effective half-life $\left(t_{1 / 2}(\mathrm{eff}) / \mathrm{h}\right)$ for whole-body excretion were also performed (Supplementary Figure S89) revealing no difference in the elimination rates of $\left[{ }^{89} \mathrm{Zr}\right] \mathrm{ZrFe}-6$ between the normal $(8.85 \pm 0.72 \mathrm{~h}[n=5])$ and blocking groups $(8.19 \pm 0.77 \mathrm{~h}[n=5])$. However, $\left[{ }^{89} \mathrm{Zr}\right] \mathrm{ZrFe}-[4]$ rotaxane-2-hydroxyazepin was eliminated rapidly with $t_{1 / 2}(\mathrm{eff})=0.53 \pm 0.14 \mathrm{~h}(n=3)$. Collectively, the radiochemical data, cellular studies and 
in vivo experiments demonstrate that supramolecular chemistry is a viable route toward the development of cancer-targeted radiotracers.

\section{Insert_Figure_3}

\section{Rotaxanes as a modular platform in probe design}

Synthetic flexibility to control the stoichiometry, the spatial arrangement, and the nature of the various components of the rotaxane is crucial in the development of molecular imaging probes (Figure 4a, and Supplementary Schemes S5-S8, Figures S90-S165, and Tables S5-S8). We synthesised three different [4]pseudorotaxanes (compounds 8, 11, and 13) and their ${ }^{\text {nat }}$ Ga or radioactive ${ }^{68} \mathrm{Ga}$ counterparts. The successful cooperative capture synthesis and radiolabelling of ${ }^{\text {nat } / 68} \mathrm{Ga}-8$ (and also ${ }^{\text {nat } / 68} \mathrm{Ga}-11$ and ${ }^{\text {nat/68 }} \mathrm{Ga}-13$ ) was confirmed by radio-TLC and analytical HPLC

methods (Figures $\mathbf{4 b}$ and $\mathbf{4 c}$, respectively). Metallo[4]rotaxane ${ }^{\text {nat } / 68} \mathrm{Ga}-\mathbf{8}$, features the same axle as $\mathbf{3}$ and 5, but the $\beta$-CD macrocycle was functionalised with a small-molecule urea-linked GluNH-CO-NH-Lys peptidic-inhibitor that binds to prostate-specific membrane antigen (PSMA), a well-established and clinically validated biomarker of aggressive prostate cancer (PCa). ${ }^{47-49}$

In metallo[4]rotaxane ${ }^{\text {nat } / 68} \mathrm{Ga}-11$, the position of the PSMA inhibitor was swapped to the axle termini and an alternative $\beta$-CD functionalised with an $a z a$-macrocyclic chelate (NODAGA) was synthesised (compound 9). Metallo[4]rotaxane ${ }^{\text {nat } / 68} \mathrm{Ga}-\mathbf{1 3}$ provides an analogous example where a different PSMA-binding ligand, the bioactive component of the successful ${ }^{177}$ Lu- and ${ }^{225}$ Ac-radiotherapeutic tracers of PSMA- $617,{ }^{48,49}$ was installed as a capping group at both ends of the axle. This example highlights the ability to swap the nature of the biologically active vector.

All three radiotracers, $\left[{ }^{68} \mathrm{Ga}\right] \mathrm{Ga}-\mathbf{8},\left[{ }^{68} \mathrm{Ga}\right] \mathrm{Ga}-\mathbf{1 1}$, and $\left[{ }^{68} \mathrm{Ga}\right] \mathrm{Ga}-\mathbf{1 3}$ were obtained in high decay-corrected RCYs (>99\%) and high RCPs (>98\%, measured by radioactive analytical HPLC). 
Binding and internalisation assays using LNCaP (PSMA-positive), and PC-3 (PSMA-negative) prostate cancer cells were performed to investigate if these rotaxane-based radiotracers could detect PSMA expression (Figure 4d, blue and purple bars, respectively). Here, the clinical grade radiotracer, $\left[{ }^{68} \mathrm{Ga}\right] \mathrm{GaPSMA}-11$ was used as a positive control and the non-targeted rotaxane radiotracer $\left[{ }^{68} \mathrm{Ga}\right] \mathrm{Ga}-3$ was used as a negative control. For the LNCaP cell line, additional assays using $0.1 \% \mathrm{NaN}_{3}$ (Figure $4 \mathbf{d}$, white bars) which prevents surface receptor internalisation, and blocking studies using a large excess of the Glu-NH-CO-NH-Lys compound (compound 28, Figure 4d, grey bars, and Supplementary Scheme S5) were performed. $\left[{ }^{68} \mathrm{Ga}\right] \mathrm{GaPSMA}-11$ shows the expected biochemical profile of a viable PSMA-targeted radiotracer whereby cellular associated activity was $3.85 \pm 0.64 \%(n=3)$ in untreated $\mathrm{LNCaP}$ cells and showed a statistically significant difference compared with the $\mathrm{NaN}_{3}$-treated sample $(1.81 \pm 0.87 \% ; n=3, P$-value $<0.05)$, the ligand-blocked sample $(0.22 \pm 0.06 \% ; n=3, P$-value $<0.01)$, and the PC-3 cellular control $(0.05 \pm 0.01 \% ; n=3, P$-value $<0.001)$. The control $\left[{ }^{68} \mathrm{Ga}\right] \mathrm{Ga}-\mathbf{3}$, and metallo[4]rotaxanes $\left[{ }^{68} \mathrm{Ga}\right] \mathrm{Ga}-8$ and $\left[{ }^{68} \mathrm{Ga}\right] \mathrm{Ga}-11$ showed no specific interaction with PSMA, suggesting that the Glu-NH-CO-NHLys ligand was not able to access the catalytic protein binding pocket. In contrast, $\left[{ }^{68} \mathrm{Ga}\right] \mathrm{Ga}-\mathbf{1 3}$ displayed the correct biochemical behaviour with the same binding trends observed for $\left[{ }^{68} \mathrm{Ga}\right] \mathrm{GaPSMA}-11$. The total cellular bound activity of $\left[{ }^{68} \mathrm{Ga}\right] \mathrm{Ga}-\mathbf{1 3}$ was approximately 4-fold lower than $\left[{ }^{68} \mathrm{Ga}\right] \mathrm{GaPSMA}-11$ but this was anticipated since the clinical-grade radiotracer emerged after extensive structure-activity optimisation. ${ }^{47}$ Nevertheless, these data provide an encouraging precedent that rotaxane radiotracers featuring drugs or peptides can be developed for applications in molecular imaging.

\section{Insert_Figure_4}




\section{Asymmetric rotaxanes in probe design}

Next, we reduced the number of components and synthesised both a metallo[3]semirotaxane, and a fluorescein-capped metallo[3]rotaxane for dual-modality PET/optical imaging (Figure 5, and Supplementary Schemes S9-S11, Figures S166-S245, and Tables S7-S10).

Cooperative capture was used to synthesise [2] semirotaxane $\mathbf{1 4}$ in $77 \%$ yield. During HPLC purification under acidic conditions, $\beta$-CD dissociated. Then $\mathbf{1 4}$ was metallated to give the metallo[2]rotaxanes ${ }^{\text {nat }} \mathrm{Ga}-14$ or radiolabelled $\left[{ }^{68} \mathrm{Ga}\right] \mathrm{Ga}-14$ (Figure 5, Supplementary Schemes S9-S10, Figures S166-S193, Tables S7-S9). Characterisation by radio-TLC, and analytical HPLC, confirmed the successful radiosynthesis of $\left[{ }^{68} \mathrm{Ga}\right] \mathrm{Ga}-\mathbf{1 4}$ (Figures $\mathbf{5 b}$ and $\mathbf{5 c}$ ). Stability studies in water confirmed that both 14 and ${ }^{n a t} \mathrm{Ga}-14$ remained intact for at least $96 \mathrm{~h}$ (Supplementary Figure S189). Compound 14 features a bulky, lipophilic adamantyl group, which under neutral conditions, forms a tightly bound molecular inclusion complex with $\beta$-CD. ${ }^{1} \mathrm{H}-\mathrm{NMR}$ titration experiments with the intermediate adamantyl salt 37 and $\beta$-CD gave an average binding constant for the $\{\beta-C D: 37\}$ inclusion complex of $K_{\mathrm{a}}=19883 \pm 4429 \mathrm{M}^{-1}$ (Supplementary Figures S172-S178, and Table S7). Molecular inclusion reactions between 14 or ${ }^{\text {nat } / 68} \mathrm{Ga}-14$, and $\beta-\mathrm{CD}$ in water produced the [3]semirotaxane, $\mathbf{1 4} \supset \beta-\mathrm{CD}$, and the metallo[3]semirotaxanes ${ }^{\text {nat } / 68} \mathrm{Ga}-14 \supset \beta$ CD (Supplementary Figures S190-S193). Stability studies in human serum (Figure 5d, and Supplementary Figure S194 and Table S9) indicated that $\left[{ }^{68} \mathrm{Ga}\right] \mathrm{Ga}-\mathbf{1 4}$ degraded but $\left[{ }^{68} \mathrm{Ga}\right] \mathrm{Ga}$ 14 $\supset \beta$-CD remained stable. We also prepared molecular inclusion complexes with the PSMAtargeted $\beta$-CD-derivative 7 to give the [3]semirotaxanes $\mathbf{1 4} \supset 7$, and ${ }^{\text {nat } / 68} \mathrm{Ga}-\mathbf{1 4} \supset 7$ (Supplementary Figures S195-S198). Cellular binding studies were performed with the non-targeted $\left[{ }^{68} \mathrm{Ga}\right] \mathrm{Ga}-$ 14 $\supset \beta$-CD and the PSMA-targeted $\left[{ }^{68} \mathrm{Ga}\right] \mathrm{Ga}-\mathbf{1 4} \supset 7$ species (Supplementary Figure S199). The absolute cellular uptake was low, but encouragingly, the PSMA-targeted $\left[{ }^{68} \mathrm{Ga}\right] \mathrm{Ga}-\mathbf{1 4} \supset \mathbf{7}$ displayed 
the correct biochemical behaviour with a $\sim 75 \%$ decrease in binding between the LNCaP (PSMApositive) and the PC-3 (PSMA-negative) cells.

As a second example, we synthesised the [3] semirotaxane 15 in $34 \%$ isolated yield. Metallation gave the corresponding metallo[3]rotaxanes ${ }^{\text {nat }} \mathrm{Ga}-\mathbf{1 5}$ and $\left[{ }^{68} \mathrm{Ga}\right] \mathrm{Ga}-\mathbf{1 5}$. Compound $\mathbf{1 5}$ features an asymmetric axle capped by a (radio)metal ion complex and a fluorescein derivative for potential applications in dual-modality PET/optical fluorescence imaging (Figure 5, Supplementary Scheme S11, Figures S200-S245, and Table S10). Radio-TLC and analytical HPLC confirmed the successful radiosynthesis and high chemical purity $(>95 \%)$ and RCP ( $>98 \%)$ of $\left[{ }^{68} \mathrm{Ga}\right] \mathrm{Ga}-15$ (Figures 5b and 5c). ${ }^{1} \mathrm{H}-\mathrm{NMR}$ titrations indicated that the biphenyl-polyethylene glycol (PEG) intermediate 42, and the biphenyl-fluorescein compound 43, form 1:1 inclusion complexes with $\beta-\mathrm{CD}$, where the average binding constants were $K_{\mathrm{a}}(\mathbf{4 2} \supset \beta-\mathrm{CD})=2340 \pm 577 \mathrm{M}^{-1}$ and $K_{\mathrm{a}}(\mathbf{4 3} \supset \beta-\mathrm{CD})=167 \pm 70 \mathrm{M}^{-1}$ (Supplementary Figures S223-S233, and Table S10). In contrast to the 1-minute reaction times required for the synthesis of symmetrical [4]pseudorotaxanes $\mathbf{3}$ and $\mathbf{5}$, the synthesis of $\mathbf{1 5}$ required heating for $12 \mathrm{~h}$. Conformational equilibrium where the $\beta-\mathrm{CD}$ macrocycle resides primarily over the $\mathrm{PEG}_{2}$ chain would reduce the interaction between the $\mathrm{CB}[6]$ and $\beta-\mathrm{CD}$ macrocycles, decreasing the rate of the cooperative capture process. ${ }^{32-36}$

\section{Insert_Figure_5}

\section{CONCLUSIONS}

We have demonstrated a rotaxane-based strategy for the synthesis of viable molecule imaging probes that target cancer biomarkers in vitro and in vivo. We demonstrate the synthetic flexibility of the cooperative capture method to create complex, multifunctional MIMs that can be tagged to biologically active vectors including proteins (mAbs) and small molecule drugs including a 
peptidic-PSMA inhibitor. Tumour-specific uptake of a supramolecular radiotracer was observed in vivo by using PET imaging and biodistribution analysis to study the pharmacokinetics of $\left[{ }^{89} \mathrm{Zr}\right] \mathrm{ZrFe}-[4]$ rotaxane-trastuzumab. Synthetic variations of the rotaxane architecture were also explored, demonstrating that the system composition can be tuned. Collectively, the experimental data provide compelling evidence that rotaxane-based supramolecular chemistry is a versatile platform for designing novel molecular imaging probes that target biomarkers of disease.

\section{ASSOCIATED CONTENT}

Supplementary information (PDF) is available and contains experimental details, NMR spectra, high-resolution mass spectrometry data and HPLC chromatograms for all compounds, as well as additional data from the radiochemistry, in vivo experiments, and DFT calculations.

\section{AUTHOR INFORMATION}

\section{Corresponding author}

Jason P. Holland - University of Zurich, Department of Chemistry, Winterthurerstrasse 190, CH8057, Zurich, Switzerland; ORCID: orcid.org/0000-0002-0066-219X; Email: jason.holland@chem.uzh.ch; Website: www.hollandlab.org

\section{Authors}

Faustine d'Orchymont - University of Zurich, Department of Chemistry, Winterthurerstrasse 190, CH-8057, Zurich, Switzerland. ORCID: orcid.org/0000-0002-3726-1648

\section{Author contributions}


FdO and JPH designed all experiments, analysed the data, and wrote the manuscript. FdO conducted all experiments including the synthesis, characterisation, radiochemistry, cellular studies, and imaging in vivo. JPH assisted with the radiochemistry and animal experiments, performed DFT calculations, and supervised the project. FdO and JPH wrote the manuscript.

\section{Competing interests}

There are no competing interests.

\section{ACKNOWLEDGMENTS}

JPH is supported by the Swiss National Science Foundation (SNSF Professorship PP00P2_163683 and PP00P2_190093) and the University of Zurich (UZH) for financial support. FdO received a Swiss Government Excellence Scholarship (ESKAS-Nr: 2017.0043). We thank all members of the Holland group for helpful discussions and continuous support. We thank Prof. Chenfeng Ke, Prof. Michal Juricek and Prof. Oliver Zerbe for helpful discussions. 


\section{REFERENCES}

(1) Bruns, C. J.; Stoddart, J. F. The Nature of the Mechanical Bond; 2016.

(2) Neal, E. A.; Goldup, S. M. Chemical Consequences of Mechanical Bonding in Catenanes and Rotaxanes: Isomerism, Modification, Catalysis and Molecular Machines for Synthesis. Chem. Commun. 2014, 50 (40), 5128-5142.

https://doi.org/10.1039/c3cc47842d.

(3) Livoreil, A.; Dietrich-Buchecker, C.; Sauvage, J. Electrochemically Triggerred Swinging of a [2]Catenate. J. Am. Chem. Soc. 1994, 116, 9399-9400.

(4) Bissell, R. A.; Cordova, E.; Kaifer, A. E.; Stoddart, J. F. A Chemically and Electrochemically Switchable Molecular Shuttle. Nature 1994, 369, 133-137.

(5) Erbas-Cakmak, S.; Leigh, D. A.; McTernan, C. T.; Nussbaumer, A. L. Artificial Molecular Machines. Chem. Rev. 2015, 115 (18), 10081-10206. https://doi.org/10.1021/acs.chemrev.5b00146.

(6) Fletcher, S. P.; Dumur, F.; Pollard, M. M.; Feringa, B. L. A Reversible, Unidirectional Molecular Rotary Motor Driven by Chemical Energy. Science (80-. ). 2005, 310 (October), 80-83.

(7) Van Dongen, S. F. M.; Cantekin, S.; Elemans, J. A. A. W.; Rowan, A. E.; Nolte, R. J. M. Functional Interlocked Systems. Chem. Soc. Rev. 2014, 43 (1), 99-122. https://doi.org/10.1039/c3cs60178a.

(8) Luo, Y.; Collier, C. P.; Jeppesen, J. O.; Nielsen, K. A.; DeIonno, E.; Ho, G.; Perkins, J.; Tseng, H. R.; Yamamoto, T.; Stoddart, J. F.; Heath, J. R. Two-Dimensional Molecular Electronics Circuits. ChemPhysChem 2002, 3 (6), 519-525. https://doi.org/10.1002/14397641(20020617)3:6<519::AID-CPHC519>3.0.CO;2-2.

(9) Angelos, S.; Yang, Y.; Patel, K.; Stoddart, J. F.; Zink, J. I. PH-Responsive Supramolecular Nanovalves Based on Cucurbi[6]Uril Pseudorotaxanes. Angew. Chemie Int. Ed. 2008, 120, 2254-2258. https://doi.org/10.1002/ange.200705211.

(10) Galli, M.; Lewis, J. E. M.; Goldup, S. M. A Stimuli-Responsive Rotaxane-Gold Catalyst: Regulation of Activity and Diastereoselectivity. Angew. Chemie - Int. Ed. 2015, 54 (46), 13545-13549. https://doi.org/10.1002/anie.201505464.

(11) Heard, A. W.; Goldup, S. M. Synthesis of a Mechanically Planar Chiral Rotaxane Ligand for Enantioselective Catalysis. Chem 2020, 6 (4), 994-1006. https://doi.org/10.1016/j.chempr.2020.02.006.

(12) Pairault, N.; Barat, R.; Tranoy-Opalinski, I.; Renoux, B.; Thomas, M.; Papot, S. RotaxaneBased Architectures for Biological Applications. Comptes Rendus Chim. 2016, 19 (1-2), 103-112. https://doi.org/10.1016/j.crci.2015.05.012.

(13) Casini, A.; Woods, B.; Wenzel, M. The Promise of Self-Assembled 3D Supramolecular Coordination Complexes for Biomedical Applications. Inorg. Chem. 2017, 56 (24), 14715-14729. https://doi.org/10.1021/acs.inorgchem.7b02599.

(14) Wang, X.; Smithrud, D. B. Pt-Rotaxanes as Cytotoxic Agents. Bioorg. Med. Chem. Lett. 2011, 21 (22), 6880-6883. https://doi.org/10.1016/j.bmcl.2011.09.007.

(15) Smithrud, D. B.; Powers, L.; Lunn, J.; Abernathy, S.; Peschka, M.; Ho, S. mei; Tarapore, P. Ca2+ Selective Host Rotaxane Is Highly Toxic Against Prostate Cancer Cells. ACS Med. Chem. Lett. 2017, 8 (2), 163-167. https://doi.org/10.1021/acsmedchemlett.6b00347.

(16) Sojka, M.; Fojtu, M.; Fialova, J.; Masarik, M.; Necas, M.; Marek, R. Locked and Loaded: Ruthenium(II)-Capped Cucurbit[ n]Uril-Based Rotaxanes with Antimetastatic Properties. 
Inorg. Chem. 2019, 58 (16), 10861-10870.

https://doi.org/10.1021/acs.inorgchem.9b01203.

(17) Webber, M. J.; Langer, R. Drug Delivery by Supramolecular Design. Chem. Soc. Rev. 2017, 46 (21), 6600-6620. https://doi.org/10.1039/c7cs00391a.

(18) Barat, R.; Legigan, T.; Tranoy-Opalinski, I.; Renoux, B.; Péraudeau, E.; Clarhaut, J.; Poinot, P.; Fernandes, A. E.; Aucagne, V.; Leigh, D. A.; Papot, S. A Mechanically Interlocked Molecular System Programmed for the Delivery of an Anticancer Drug. Chem. Sci. 2015, 6 (4), 2608-2613. https://doi.org/10.1039/c5sc00648a.

(19) Schmidt, A.; Molano, V.; Hollering, M.; Pöthig, A.; Casini, A.; Kühn, F. E. Evaluation of New Palladium Cages as Potential Delivery Systems for the Anticancer Drug Cisplatin. Chem. - A Eur. J. 2016, 22 (7), 2253-2256. https://doi.org/10.1002/chem.201504930.

(20) Hannon, M. J. Supramolecular DNA Recognition. Chem. Soc. Rev. 2007, 36 (2), 280-295. https://doi.org/10.1039/b606046n.

(21) Fernandes, A.; Viterisi, A.; Coutrot, F.; Potok, S.; Leigh, D. A.; Aucagne, V.; Papot, S. Rotaxane-Based Propeptides: Protection and Enzymatic Release of a Bioactive Pentapeptide. Angew. Chemie - Int. Ed. 2009, 48 (35), 6443-6447. https://doi.org/10.1002/anie.200903215.

(22) Fernandes, A.; Viterisi, A.; Aucagne, V.; Leigh, D. A.; Papot, S. Second Generation Specific-Enzyme-Activated Rotaxane Propeptides. Chem. Commun. 2012, 48 (15), $2083-$ 2085. https://doi.org/10.1039/c2cc17458h.

(23) Burke, B. P.; Grantham, W.; Burke, M. J.; Nichol, G. S.; Roberts, D.; Renard, I.; Hargreaves, R.; Cawthorne, C.; Archibald, S. J.; Lusby, P. J. Visualizing Kinetically Robust CoIII4L6 Assemblies in Vivo: SPECT Imaging of the Encapsulated [99mTc]TcO4- Anion. J. Am. Chem. Soc. 2018, 140, 16877-16881. https://doi.org/10.1021/jacs.8b09582.

(24) Woods, B.; Silva, R. D. M.; Schmidt, C.; Wragg, D.; Cavaco, M.; Neves, V.; Ferreira, V. F. C.; Gano, L.; Morais, T. S.; Mendes, F.; Correia, J. D. G.; Casini, A. Bioconjugate Supramolecular Pd2+Metallacages Penetrate the Blood Brain Barrier in Vitro and in Vivo. Bioconjug. Chem. 2021, 32, 1399-1408. https://doi.org/10.1021/acs.bioconjchem.0c00659.

(25) Arunkumar, E.; Fu, N.; Smith, B. D. Squaraine-Derived Rotaxanes : Highly Stable, Fluorescent Near-IR Dyes. Chem. - A Eur. J. 2006, 12, 4684-4690. https://doi.org/10.1002/chem.200501541.

(26) Gassensmith, J. J.; Baumes, J. M.; Smith, B. D. Discovery and Early Development of Squaraine Rotaxanes. Chem. Commun. 2009, No. 42, 6329-6338. https://doi.org/10.1039/b911064j.

(27) Zhai, C.; Schreiber, C. L.; Padilla-coley, S.; Oliver, A. G.; Smith, B. D. Fluorescent SelfThreaded Peptide Probes for Biological Imaging Research Articles. Angew. Chemie - Int. Ed. 2020, 59, 23740-23747. https://doi.org/10.1002/anie.202009599.

(28) Fredy, J. W.; Scelle, J.; Guenet, A.; Morel, E.; Adam De Beaumais, S.; Ménand, M.; Marvaud, V.; Bonnet, C. S.; Tõth, E.; Sollogoub, M.; Vives, G.; Hasenknopf, B. Cyclodextrin Polyrotaxanes as a Highly Modular Platform for the Development of Imaging Agents. Chem. - A Eur. J. 2014, 20 (35), 10915-10920. https://doi.org/10.1002/chem.201403635.

(29) Fredy, J. W.; Scelle, J.; Ramniceanu, G.; Doan, B. T.; Bonnet, C. S.; Tóth, É.; Ménand, M.; Sollogoub, M.; Vives, G.; Hasenknopf, B. Mechanostereoselective One-Pot Synthesis 
of Functionalized Head-to-Head Cyclodextrin [3]Rotaxanes and Their Application as Magnetic Resonance Imaging Contrast Agents. Org. Lett. 2017, 19 (5), 1136-1139. https://doi.org/10.1021/acs.orglett.7b00153.

(30) Oshovsky, G. V.; Reinhoudt, D. N.; Verboom, W. Supramolecular Chemistry in Water. Angew. Chemie - Int. Ed. 2007, 46 (14), 2366-2393. https://doi.org/10.1002/anie.200602815.

(31) Bruns, C. J.; Liu, H.; Francis, M. B. Near-Quantitative Aqueous Synthesis of Rotaxanes via Bioconjugation to Oligopeptides and Proteins. J. Am. Chem. Soc. 2016, 138 (47), 15307-15310. https://doi.org/10.1021/jacs.6b10231.

(32) Ke, C.; Smaldone, R. A.; Kikuchi, T.; Li, H.; Davis, A. P.; Stoddart, J. F. Quantitative Emergence of Hetero[4]Rotaxanes by Template-Directed Click Chemistry. Angew.

Chemie - Int. Ed. 2013, 52 (1), 381-387. https://doi.org/10.1002/anie.201205087.

(33) Hou, X.; Ke, C.; Cheng, C.; Song, N.; Blackburn, A. K.; Sarjeant, A. A.; Botros, Y. Y.; Yang, Y.-W.; Stoddart, J. F. Efficient Syntheses of Pillar[6]Arene-Based Hetero[4]Rotaxanes Using a Cooperative Capture Strategy. Chem. Commun. 2014, 50 (47), 6196-6199. https://doi.org/10.1039/C4CC00733F.

(34) Hou, X.; Ke, C.; Fraser Stoddart, J. Cooperative Capture Synthesis: Yet Another Playground for Copper-Free Click Chemistry. Chem. Soc. Rev. 2016, 45 (14), 3766-3780. https://doi.org/10.1039/c6cs00055j.

(35) Mock, W. L.; Shih, N. Y. Host-Guest Binding Capacity of Cucurbituril. J. Org. Chem. 1983, 48 (20), 3618-3619. https://doi.org/10.1021/jo00168a069.

(36) Mock, W. L.; Irra, T. A.; Wepsiec, J. P.; Adhya, M. Catalysis by Cucurbituril. The Significance of Bound-Substrate Destabilization for Induced Triazole Formation. J. Org. Chem. 1989, 54 (22), 5302-5308. https://doi.org/10.1021/jo00283a024.

(37) Tuncel, D.; Steinke, J. H. G. Catalytically Self-Threading Polyrotaxanes. Chem. Commun. 1999, 1509-1510.

(38) Finbloom, J. A.; Han, K.; Slack, C. C.; Furst, A. L.; Francis, M. B. Cucurbit[6]UrilPromoted Click Chemistry for Protein Modification. J. Am. Chem. Soc. 2017, 139 (28), 9691-9697. https://doi.org/10.1021/jacs.7b05164.

(39) Frisch, M. J.; Trucks, G. W.; Schlegel, H. B.; Scuseria, G. E.; Robb, M. A.; Cheeseman, J. R.; Scalmani, G.; Barone, V.; Mennucci, B.; Petersson, G. A.; Nakatsuji, H.; Caricato, M.; Li, X.; Hratchian, H. P.; Izmaylov, A. F.; Bloino, J.; Zheng, G.; Sonnenberg, J. L.; Hada, M.; Ehara, M.; Toyota, K.; Fukuda, R.; Hasegawa, J.; Ishida, M.; Nakajima, T.; Honda, Y.; Kitao, O.; Nakai, H.; Vreven, T.; Montgomery Jr., J. A.; Peralta, J. E.; Ogliaro, F.; Bearpark, M.; Heyd, J. J.; Brothers, E.; Kudin, K. N.; Staroverov, V. N.; Kobayashi, R.; Normand, J.; Raghavachari, K.; Rendell, A.; Burant, J. C.; Iyengar, S. S.; Tomasi, J.; Cossi, M.; Rega, N.; Millam, J. M.; Klene, M.; Knox, J. E.; Cross, J. B.; Bakken, V.; Adamo, C.; Jaramillo, J.; Gomperts, R.; Stratmann, R. E.; Yazyev, O.; Austin, A. J.; Cammi, R.; Pomelli, C.; Ochterski, J. W.; Martin, R. L.; Morokuma, K.; Zakrzewski, V. G.; Voth, G. A.; Salvador, P.; Dannenberg, J. J.; Dapprich, S.; Daniels, A. D.; Farkas, .; Foresman, J. B.; Ortiz, J. V; Cioslowski, J.; Fox, D. J. Gaussian16 (Revision A.03), Gaussian Inc. Wallingford CT. Gaussian16 (Revision A.03). 2016.

(40) Guillou, A.; Earley, D. F.; Patra, M.; Holland, J. P. Light-Induced Synthesis of Protein Conjugates and Its Application in Photoradiosynthesis of $89 \mathrm{Zr}$-Radiolabeled Monoclonal Antibodies. Nat. Protoc. 2020, 15 (11), 3579-3594. https://doi.org/10.1038/s41596-0200386-5. 
(41) Patra, M.; Eichenberger, L. S.; Fischer, G.; Holland, J. P. Photochemical Conjugation and One-Pot Radiolabelling of Antibodies for Immuno-PET. Angew. Chemie - Int. Ed. 2019, 58 (7), 1928-1933. https://doi.org/10.1002/anie.201813287.

(42) Patra, M.; Klingler, S.; Eichenberger, L. S.; Holland, J. Simultaneous Photoradiochemical Labelling of Antibodies for Immuno-Positron Emission Tomography. iScience 2019, 13, 416-431. https://doi.org/10.1016/ j.isci.2019.03.004.

(43) Holland, J. P. Predicting the Thermodynamic Stability of Zirconium Radiotracers. Inorg. Chem. 2020, 59 (3). https://doi.org/10.1021/acs.inorgchem.9b03515.

(44) Konishi, S.; Hamacher, K.; Vallabhajosula, S.; Kothari, P.; Bastidas, D.; Bander, N.; Goldsmith, S. Determination of Immunoreactive Fraction of Radiolabeled Monoclonal Antibodies: What Is an Appropriate Method? Cancer Biother. Radiopharm. 2004, 19 (6), 706-715. https://doi.org/10.1089/cbr.2004.19.706.

(45) Gritsan, N. P.; Platz, M. S. Kinetics, Spectroscopy, and Computational Chemistry of Arylnitrenes. Chem. Rev. 2006, 106 (9), 3844-3867. https://doi.org/10.1021/cr040055+.

(46) Guillou, A.; Earley, D. F.; Klingler, S.; Nisli, E.; Nüesch, L. J.; Fay, R.; Holland, J. P. The Influence of a Polyethylene Glycol Linker on the Metabolism and Pharmacokinetics of a 89Zr-Radiolabeled Antibody. Bioconjug. Chem. 2021, 32 (7), 1263-1275. https://doi.org/10.1021/acs.bioconjchem.1c00172.

(47) Eder, M.; Schäfer, M.; Bauder-Wüst, U.; Hull, W. E.; Wängler, C.; Mier, W.; Haberkorn, U.; Eisenhut, M. 68Ga-Complex Lipophilicity and the Targeting Property of a Urea-Based PSMA Inhibitor for PET Imaging. Bioconjug. Chem. 2012, 23 (4), 688-697. https://doi.org/10.1021/bc200279b.

(48) Kratochwil, C.; Giesel, F. L.; Stefanova, M.; Benesova, M.; Bronzel, M.; AfsharOromieh, A.; Mier, W.; Eder, M.; Kopka, K.; Haberkorn, U. PSMA-Targeted Radionuclide Therapy of Metastatic Castration-Resistant Prostate Cancer with 177LuLabeled PSMA-617. J. Nucl. Med. 2016, 57 (8), 1170-1176. https://doi.org/10.2967/jnumed.115.171397.

(49) Kratochwil, C.; Bruchertseifer, F.; Giesel, F. L.; Weis, M.; Verburg, F. A.; Mottaghy, F.; Kopka, K.; Apostolidis, C.; Haberkorn, U.; Morgenstern, A. 225Ac-PSMA-617 for PSMA-Targeted -Radiation Therapy of Metastatic Castration-Resistant Prostate Cancer. J. Nucl. Med. 2016, 57 (12), 1941-1944. https://doi.org/10.2967/jnumed.116.178673.

(50) Grimme, S.; Hansen, A.; Brandenburg, J. G.; Bannwarth, C. Dispersion-Corrected MeanField Electronic Structure Methods. Chem. Rev. 2016, 116 (9), 5105-5154. https://doi.org/10.1021/acs.chemrev.5b00533. 
Figure 1. Prominent examples of supramolecular complexes developed as molecular imaging agents. (a) Tetrahedral $\mathrm{Co}^{3+}$-macrocyclic cages encapsulating $\left[{ }^{99 \mathrm{~m}} \mathrm{Tc}\right] \mathrm{TcO}_{4}{ }^{-}$for $\mathrm{SPECT}$ imaging. ${ }^{23}$ (b) Peptide-functionalised $\mathrm{Pd}^{2+}$-macrocyclic cages encapsulating $\left[{ }^{99 \mathrm{~m}} \mathrm{Tc}\right] \mathrm{TcO}_{4}{ }^{-}$for SPECT, and featuring blood-brain barrier penetrant translocating sequences. ${ }^{24}$ (c) Optically active squarainedye knots for fluorescence imaging of cellular surface markers. ${ }^{27}$ (d) Cooperative capture synthesis of rotaxanes featuring curcurbit[6]uril, cyclodextrin, and pillar[n]arene macrocycles. ${ }^{32-34}$ (e) Schematic overview of our approach toward cancer-targeted rotaxanes for PET/optical imaging.
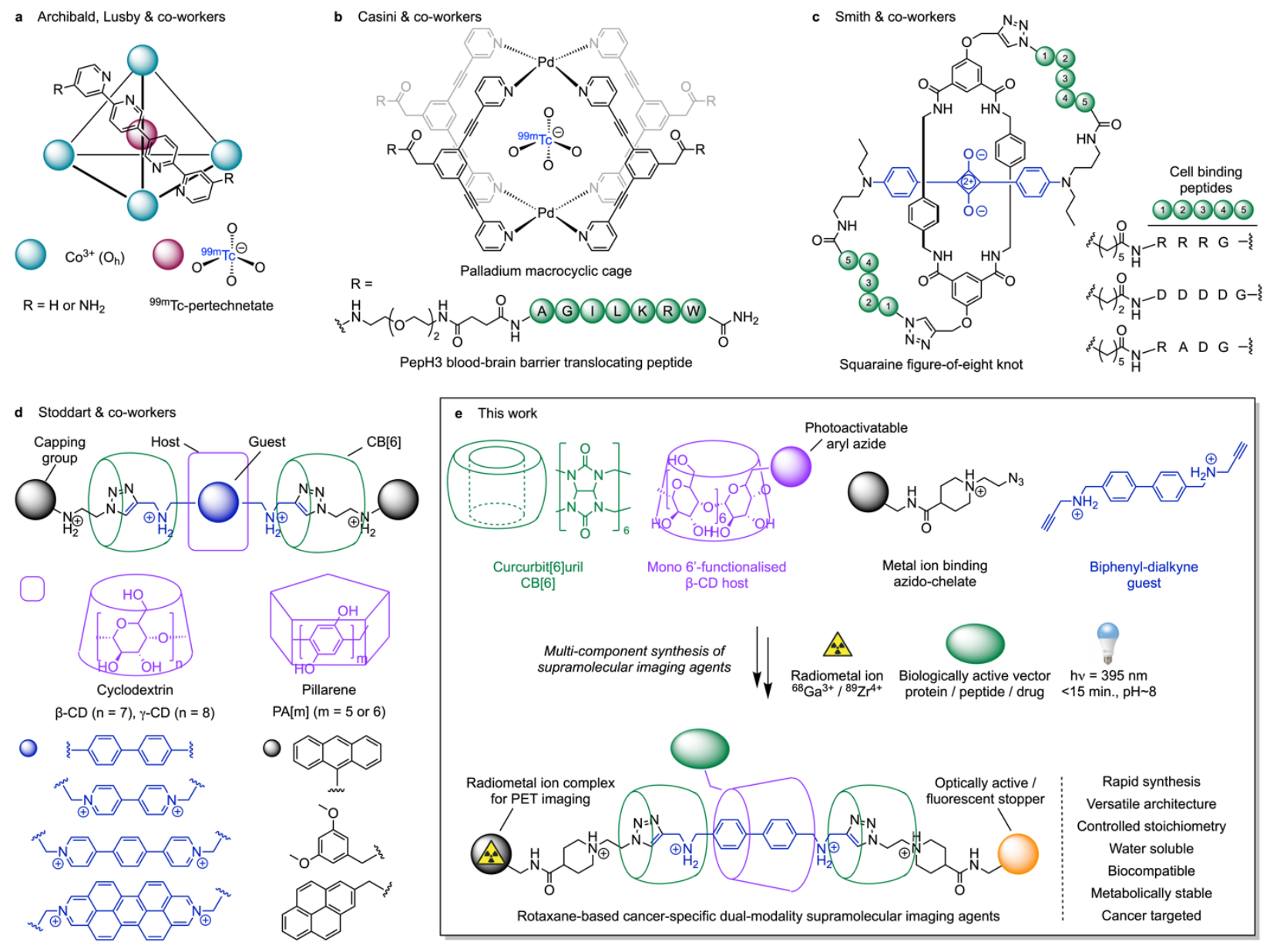
Figure 2. Proof-of-concept synthesis of a radiolabelled rotaxane. (a) Scheme for the synthesis of the [4]pseudorotaxane 3 and the equivalent metallo[4]rotaxanes labelled with either natural nonradioactive ${ }^{\text {nat }} \mathrm{Ga}^{3+}$ or ${ }^{\text {nat }} \mathrm{Zr}^{4+}$ ions or the positron-emitting radioactive ions ${ }^{68} \mathrm{Ga}^{3+}\left(t_{1 / 2}=67.7 \mathrm{~min}\right.$. $)$ or ${ }^{89} \mathrm{Zr}^{4+}\left(t_{1 / 2}=78.41 \mathrm{~h}\right)$. (b) Selected region of the ${ }^{1} \mathrm{H}$ NMR spectra of $\mathbf{1}$, the molecular inclusion complex $\mathbf{1} \supset \beta-\mathrm{CD}$, and [4]pseudorotaxane $\mathbf{3}$ showing the splitting of the biphenyl-alkyne aromatic protons into 4 distinct environments in the [4]pseudorotaxane. (c) Radio-thin-layer chromatography (radio-TLC) chromatograms showing the successful radiosynthesis of metallo[4]rotaxanes $\left[{ }^{68} \mathrm{Ga}\right] \mathrm{Ga}-3$ (blue) and $\left[{ }^{89} \mathrm{Zr}\right] \mathrm{Zr}-\mathbf{3}$ (orange). Controls show the elution of free $\left[{ }^{68} \mathrm{Ga}\right]\left[\mathrm{Ga}(\text { citrate })_{2}\right]^{3-}$ (pink) and $\left[{ }^{89} \mathrm{Zr}\right][\mathrm{Zr}(\mathrm{DTPA})]^{-}$(grey; where DTPA $=N, N, N^{\prime}, N^{\prime}-$ diethylenetriamine pentaacetic acid) under the radio-TLC conditions. (d) Analytical HPLC chromatograms showing the elution profile of $\mathbf{3}$ (black) and the metallo[4]rotaxanes ${ }^{\text {nat }} \mathrm{Ga}-\mathbf{3}$ (purple), $\left[{ }^{68} \mathrm{Ga}\right] \mathrm{Ga}-3$ (blue), nat $\mathrm{Zr}-3$ (green), $\left[{ }^{89} \mathrm{Zr}\right] \mathrm{Zr}-3$ (orange). Note: non-radioactive samples were monitored by electronic absorption at $254 \mathrm{~nm}$. (e) Plot showing the relative stability versus time (measured by HPLC peak integration) of metallo[4]rotaxanes ${ }^{\text {nat }} \mathrm{Ga}-\mathbf{3}$ (purple) and ${ }^{\text {nat }} \mathrm{Zr}-\mathbf{3}$ (green) versus the dethreading of [4]pseudorotaxane 3 (black) in water $\left(\mathrm{pH} 6-7,23{ }^{\circ} \mathrm{C}\right)$. (f) Optimised structure of the model [4]pseudorotaxane showing the axle curvature and the spatial arrangement $\mathrm{CB}[6]$ and $\beta-\mathrm{CD}$ macrocycles calculated by using dispersion-corrected ${ }^{50}$ density functional theory (B3LYP-D3/DGDZVP/PCM) with Gaussian16. ${ }^{39}$ 
a

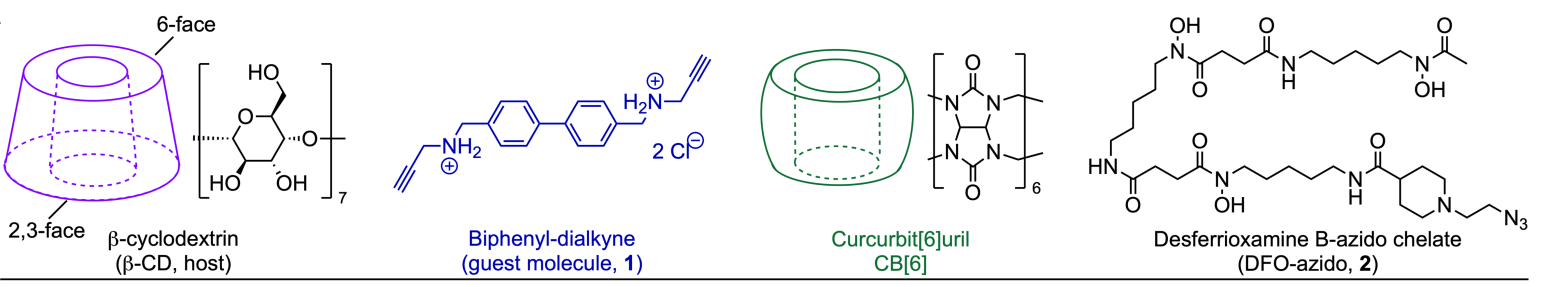

\begin{tabular}{c|c}
$\begin{array}{c}\text { Cooperative capture } \\
\text { self-assembly }\end{array}$ & $\mathrm{H}_{2} \mathrm{O}$ \\
$70^{\circ} \mathrm{C}, 1$ min \\
Purification by HPLC
\end{tabular}

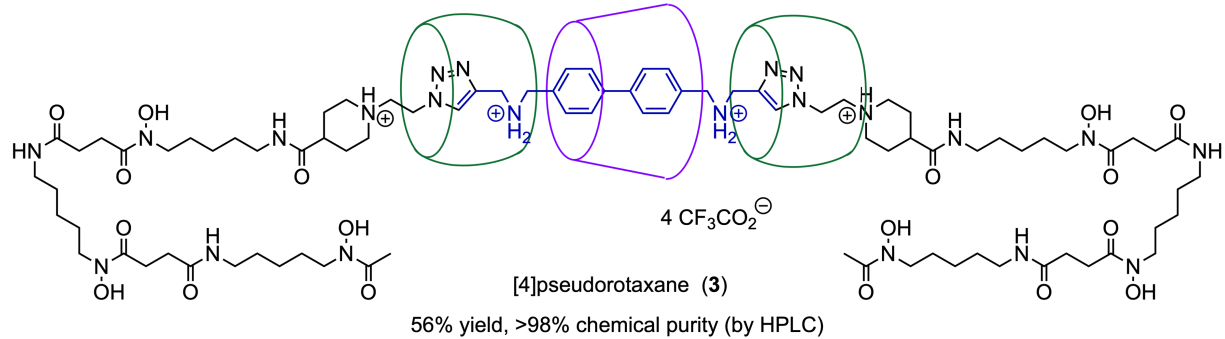

$56 \%$ yield, $>98 \%$ chemical purity (by HPLC)

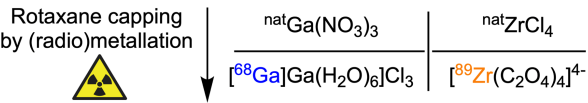

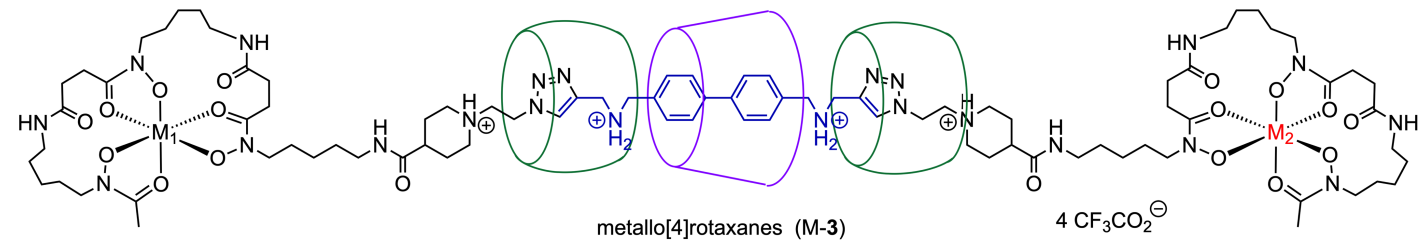

\begin{tabular}{|c|c|c|c|c|c|c|c|c|c|c|c|c|}
\hline \multirow[b]{2}{*}{ Compound } & \multirow[b]{2}{*}{$M_{1}$} & \multirow[b]{2}{*}{$\mathrm{M}_{2}$} & \multirow{2}{*}{\multicolumn{2}{|c|}{ Isolated yield }} & \multirow{2}{*}{$\begin{array}{c}\text { Chemical } \\
\text { purity (HPLC) }\end{array}$} & \multirow[b]{2}{*}{$\mathrm{RCY}$} & \multirow[b]{2}{*}{$\mathrm{RCP}$} & \multirow[b]{2}{*}{ Molecular formula } & \multirow{2}{*}{\multicolumn{2}{|c|}{ Ion / Abundance }} & \multicolumn{2}{|c|}{ Isotopic mass } \\
\hline & & & & & & & & & & & Calculated & Found \\
\hline 3 & $3 \times \mathrm{H}$ & $3 \times \mathrm{H}$ & & $56 \%$ & $>98 \%$ & - & - & $\mathrm{C}_{200} \mathrm{H}_{287} \mathrm{~N}_{70} \mathrm{O}_{77}$ & {$[\mathrm{M}+5 \mathrm{H}]^{5+}$} & $100 \%$ & 980.2133 & 980.2135 \\
\hline${ }^{\text {nat } G a-3}$ & ${ }^{\text {nat }} \mathrm{Ga}$ & ${ }^{\text {nat }} \mathrm{Ga}$ & & $>99 \%$ & $>95 \%$ & - & - & $\mathrm{C}_{200} \mathrm{H}_{281} \mathrm{~N}_{70} \mathrm{O}_{77} \mathrm{Ga}_{2}$ & {$[\mathrm{M}+5 \mathrm{H}]^{5+}$} & $100 \%$ & 1006.5742 & 1006.5756 \\
\hline$\left[{ }^{68} \mathrm{Ga}\right] \mathrm{Ga}-3$ & ${ }^{\text {nat }} \mathrm{Ga}$ & ${ }^{68} \mathrm{Ga}$ & 8 & - & - & $>98 \%$ & $>95 \%$ & - & - & - & - & - \\
\hline nat $Z r-3$ & nat Zr & ${ }^{n a t} Z r$ & & $>99 \%$ & $>95 \%$ & - & - & $\mathrm{C}_{200} \mathrm{H}_{287} \mathrm{~N}_{70} \mathrm{O}_{77} \mathrm{Zr}_{2}$ & {$[\mathrm{M}+6 \mathrm{H}]^{6+}$} & $100 \%$ & 845.6369 & 845.6369 \\
\hline$\left[{ }^{89} \mathrm{Zr}\right] \mathrm{Zr}-3$ & ${ }^{n a t} Z r$ & ${ }^{89} \mathrm{Zr}$ & $\Delta$ & - & - & $>98 \%$ & $>90 \%$ & - & - & - & - & - \\
\hline
\end{tabular}
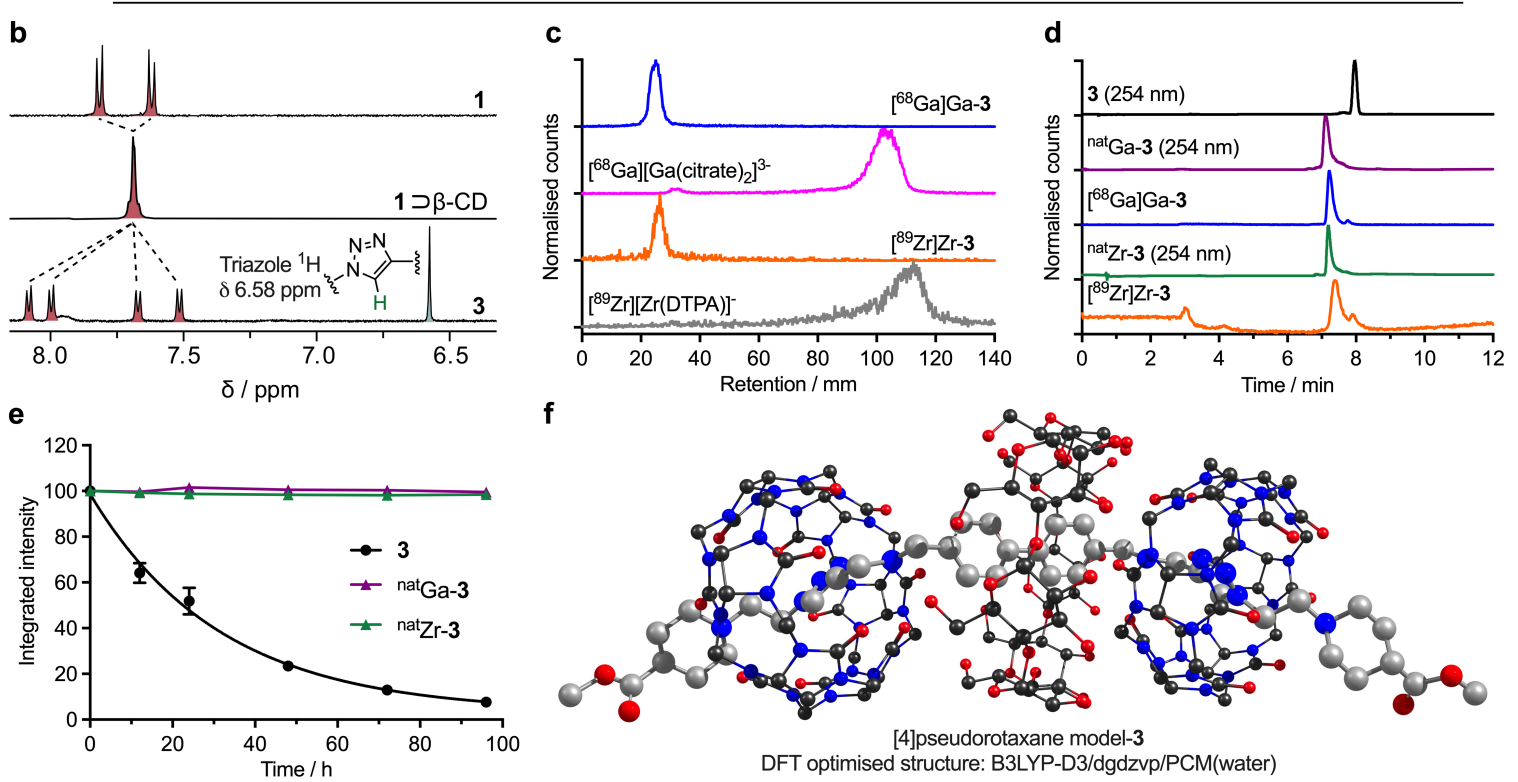

f

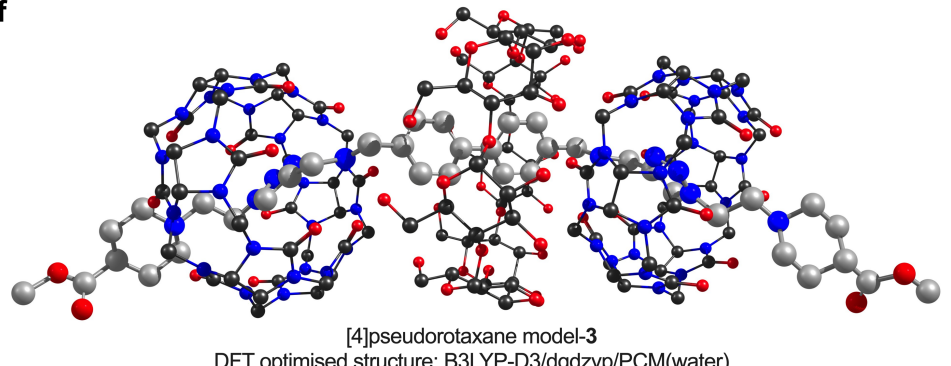

Page 24 
Figure 3. Synthesis and characterisation of ${ }^{89} \mathrm{Zr}$-radiolabelled rotaxane-trastuzumab for PET imaging of HER2/neu expression in vivo. (a) Scheme for the synthesis of the photoactivatable [4]pseudorotaxane 5 and the bimetallic $\left[{ }^{89} \mathrm{Zr}\right] \mathrm{ZrFe}-[4]$ rotaxane conjugated to trastuzumab. (b) Plot showing the relative photochemical stability versus time (measured by HPLC peak integration) of metallo[4]rotaxanes ${ }^{\text {nat }} \mathrm{Ga}-\mathbf{3}$ (purple) and ${ }^{\text {nat }} \mathrm{Ga}-\mathbf{5}$ (black) under irradiation (395 nm). (c) Radio-TLC chromatograms showing the intermediate metallo[4]rotaxane $\left.{ }^{89} \mathrm{Zr}\right] \mathrm{Zr}-5$ (green), and the crude (blue) and purified (orange) samples of $\left[{ }^{89} \mathrm{Zr}\right] \mathrm{ZrFe}-6$. (d) Analytical SECHPLC chromatograms showing the elution profile of trastuzumab (280 nm, black), and the crude (blue) and purified (detection method: radioactivity = orange, $430 \mathrm{~nm}=$ red) samples of $\left[{ }^{89} \mathrm{Zr}\right] \mathrm{ZrFe}-6$. Note: ' $\Delta$ ' denotes the monomeric mAb; '*' corresponds to an aggregated protein fraction. (e) Cellular saturation binding curves (Lindmo-type assay) ${ }^{44}$ showing the specific binding of $\left[{ }^{89} \mathrm{Zr}\right] \mathrm{ZrFe}-6$ to SK-OV-3 cells in vitro. (f) Representative PET images showing the distribution of $\left[{ }^{89} \mathrm{Zr}\right] \mathrm{ZrFe}-6\left(0.161-0.175 \mathrm{MBq}, 36-40 \mu \mathrm{g}\right.$ of protein, molar activity $A_{\mathrm{m}}=0.604-0.671 \mathrm{MBq}$ $\mathrm{nmol}^{-1}$ ) between $1-72 \mathrm{~h}$ post-intravenous administration in a female athymic nude mouse bearing a subcutaneous SK-OV-3 tumour. Control images show the modulation of tumour uptake in a blocking animal $\left(0.170-0.175 \mathrm{MBq}, 1190-1230 \mu \mathrm{g}\right.$ of protein, $\left.A_{\mathrm{m}}=0.020-0.021 \mathrm{MBq} \mathrm{nmol}^{-1}\right)$. Note: $\mathrm{T}=$ tumour, $\mathrm{H}=$ heart, $\mathrm{L}=$ liver, $\mathrm{K}=$ kidney. (g) Time-activity curves (TACs) obtained from quantitative volume-of-interest (VOI) analysis from the normal $(n=5)$, and $(\mathbf{h})$ the blocking $(n=$ 5) group of animals illustrating the tumour specificity of $\left[{ }^{89} \mathrm{Zr}\right] \mathrm{ZrFe}-6$. (i) Bar chart showing the biodistribution of $\left.{ }^{89} \mathrm{Zr}\right] \mathrm{ZrFe}-6$ in selected tissues from the normal (blue) and blocking (white) groups of animals. Grey bars show the biodistribution of the control 'metabolites' sample which primarily corresponds to $\left[{ }^{89} \mathrm{Zr}\right] \mathrm{ZrFe}$-[4]rotaxane-2-hydroxyazepin. ${ }^{46}$ 
a
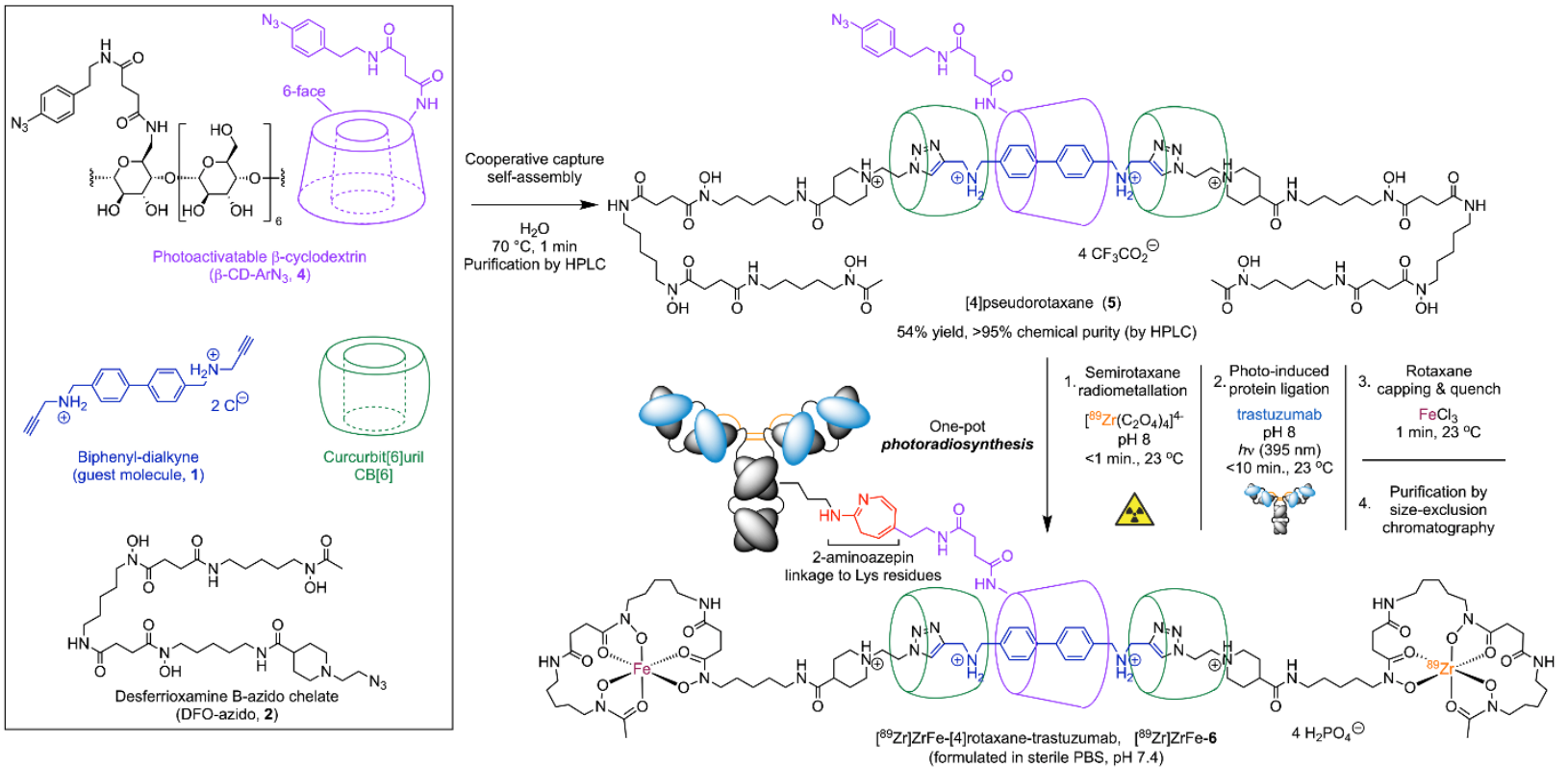

b

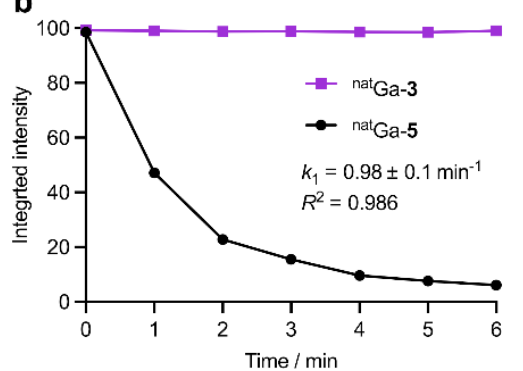

e
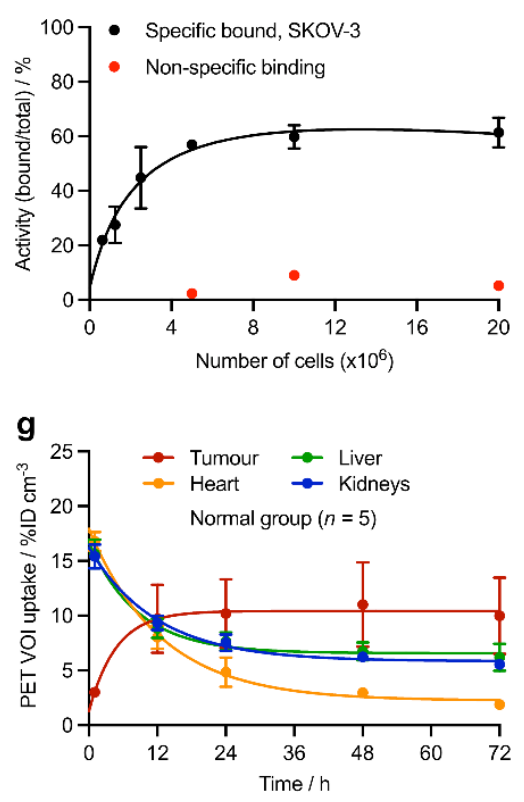

C

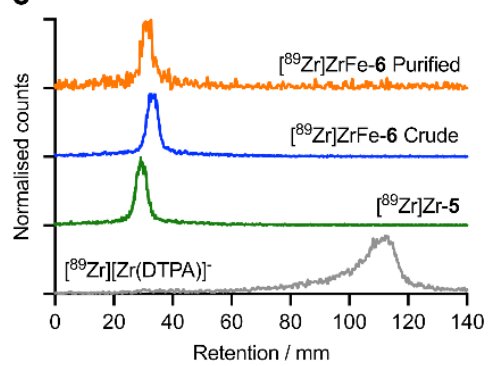

f
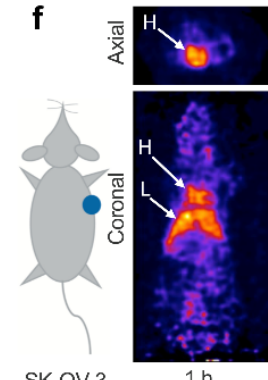

SK-OV-3

ovarian tumour $0.0 \% \mathrm{ID} \mathrm{cm}$
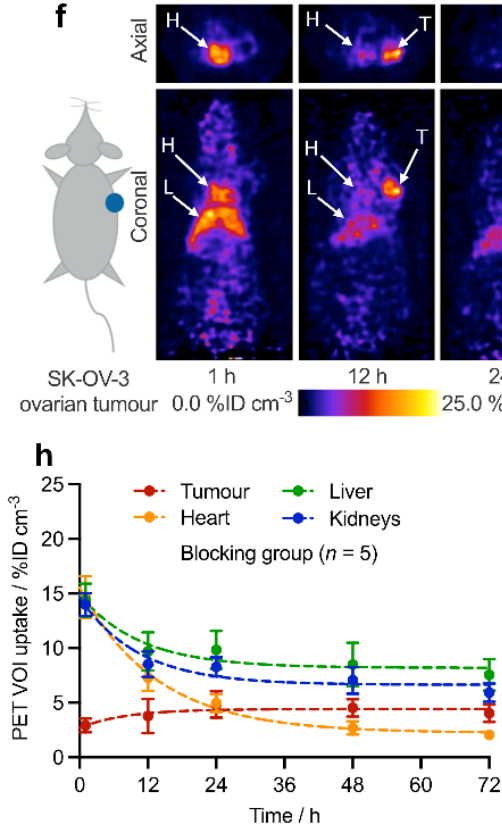

d
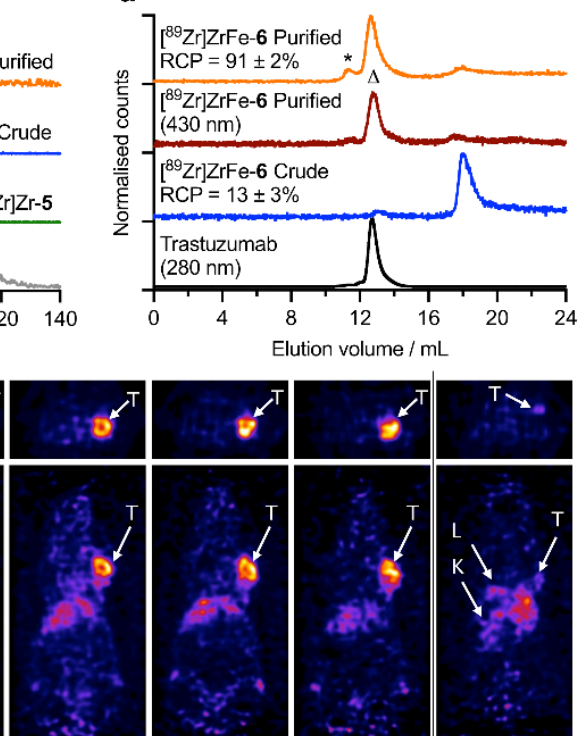

$48 \mathrm{~h}$

in volume / $\mathrm{mL}$

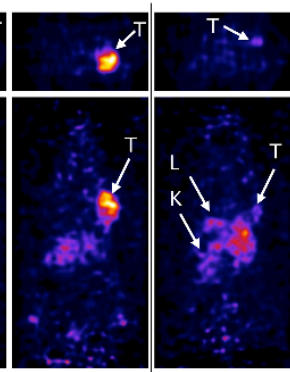

$72 \mathrm{~h}$

$72 \mathrm{~h} \mathrm{block}$ (control)

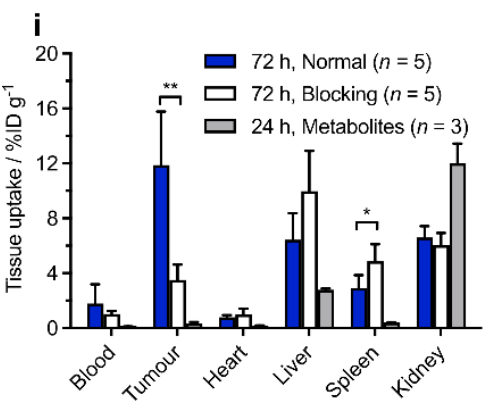


Figure 4. Rotaxane-peptide constructs with versatile topology. (a) Chemical structures of the key reagents, the [4]pseudorotaxanes $\mathbf{8}, \mathbf{1 1}$, and 13, and their ${ }^{\text {nat }} \mathrm{Ga}$ and ${ }^{68} \mathrm{Ga}$-radiolabelled metallo[4]rotaxane equivalents. (b) Radio-TLC chromatograms showing the successful radiosynthesis of $\left[{ }^{68} \mathrm{Ga}\right] \mathrm{Ga}-8$ (purple), $\left[{ }^{68} \mathrm{Ga}\right] \mathrm{Ga}-9$ (black; the ${ }^{68} \mathrm{Ga}$-labelled complex of the NODAGA-functionalised $\beta$-CD), $\left[{ }^{68} \mathrm{Ga}\right] \mathrm{Ga}-11$ (red), and $\left[{ }^{68} \mathrm{Ga}\right] \mathrm{Ga}-13$ (green). (c) Analytical reverse-phase C18 HPLC chromatograms showing the elution profile of the ${ }^{\text {nat }} \mathrm{Ga}^{3+}$ complexes (dash lines) and the radiolabelled ${ }^{68} \mathrm{Ga}^{3+}$ metallo[4]rotaxanes (solid lines) for ${ }^{\text {nat } / 68} \mathrm{Ga}-8$ (purple), ${ }^{\text {nat } / 68} \mathrm{Ga}-11$ (red),and ${ }^{\text {nat } / 68} \mathrm{Ga}-13$ (green). Note: chromatograms of the non-radiolabelled species were measured by electronic absorption at $254 \mathrm{~nm}$. (d) Bar chart showing the percentage of cellular bound activity for $\left[{ }^{68} \mathrm{Ga}\right] \mathrm{GaPSMA}-11$ (positive control), $\left[{ }^{68} \mathrm{Ga}\right] \mathrm{Ga}-3$ (negative control), and the test compounds $\left[{ }^{68} \mathrm{Ga}\right] \mathrm{Ga}-\mathbf{8},\left[{ }^{68} \mathrm{Ga}\right] \mathrm{Ga}-\mathbf{1 1}$, and $\left[{ }^{68} \mathrm{Ga}\right] \mathrm{Ga}-\mathbf{1 3}$. Note: LNCaP cells (PSMA-positive) is the positive model (blue); PC-3 cells (PSMA-negative) were used as a negative control line (purple) to measure non-specific binding. The addition of $0.1 \% \mathrm{NaN}_{3}$ to the $\mathrm{LNCaP}_{\text {binding assay }}$ (white) prevents PSMA receptor internalisation. The blocking assay (grey) provides a measure of binding specificity and involved pre-incubation of the LNCaP cells with an excess of the free GluNH-CO-NH-Lys inhibitor $28(200 \mu \mathrm{M})$. 


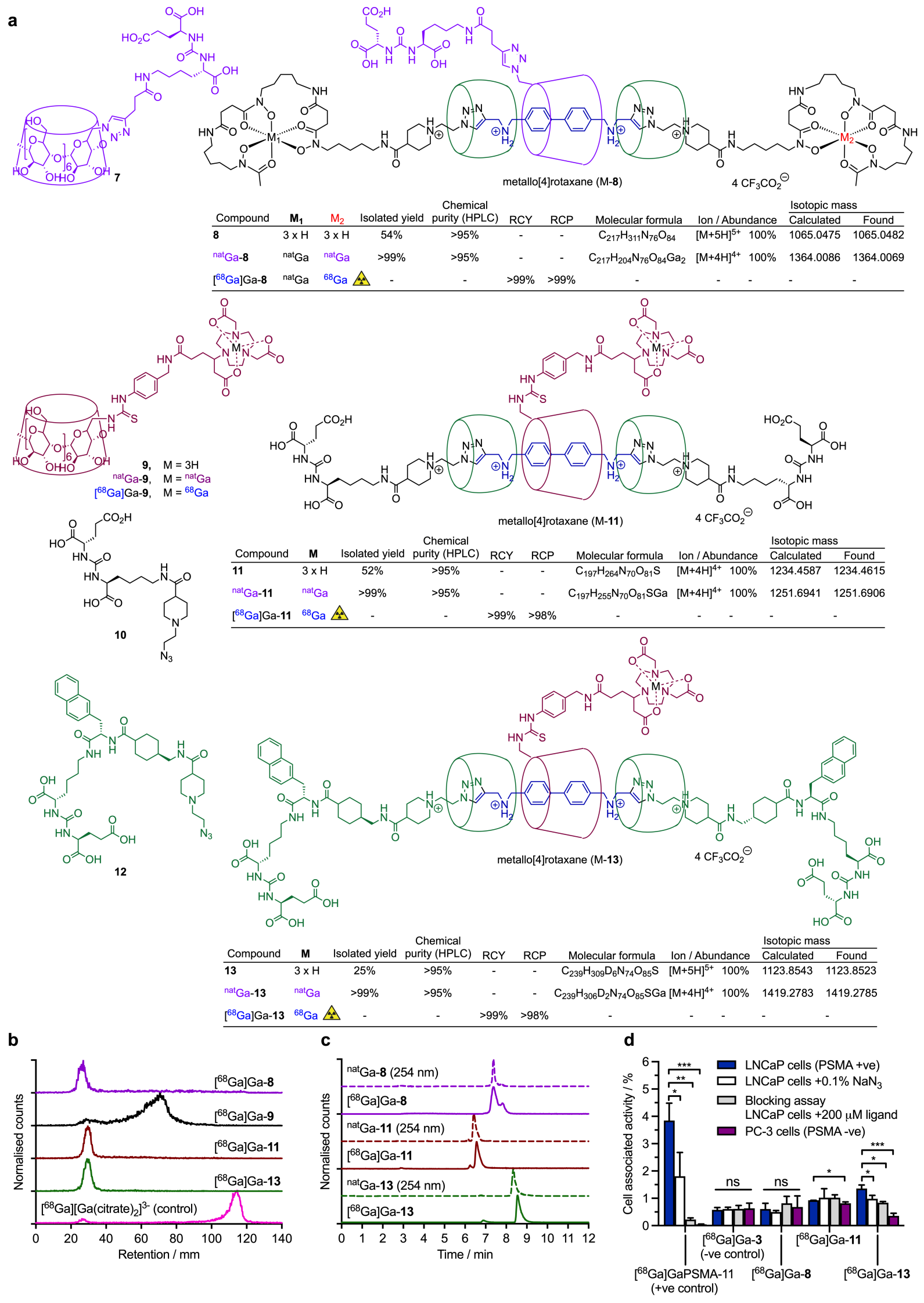

Page 28 
Figure 5. Synthesis and characterisation of a metallo[3]semirotaxane, and an asymmetric metallo[3]rotaxane for dual modality imaging. (a) Reaction scheme and chemical structures of the asymmetric [4] semirotaxanes 14 and $\mathbf{1 5}$, and $\mathrm{M}-\mathbf{1 4} \supset \mathbf{7}\left(\mathrm{M}=3 \mathrm{H}\right.$ atoms, or $\left.{ }^{\mathrm{nat} / 68} \mathrm{Ga}\right)$, and the fluorescein-conjugated metallo[3] rotaxanes ${ }^{\text {nat } / 68}$ Ga-15. (b) Radio-TLC chromatograms showing the successful radiosynthesis of metallo[2]rotaxane $\left[{ }^{68} \mathrm{Ga}\right] \mathrm{Ga}-14$ (blue), and metallo[3]rotaxane $\left[{ }^{68} \mathrm{Ga}\right] \mathrm{Ga}-15$ (orange). (c) Analytical reverse-phase C18 HPLC chromatograms showing the elution profile of 14 (black, $220 \mathrm{~nm}), 15$ (grey, $254 \mathrm{~nm}$ ), the corresponding ${ }^{\mathrm{nat}} \mathrm{Ga}^{3+}$ complexes ${ }^{\text {nat }} \mathrm{Ga}-14$, (purple), and nat $\mathrm{Ga}-15$, (green), and the radiolabelled ${ }^{68} \mathrm{Ga}^{3+}$ species $\left[{ }^{68} \mathrm{Ga}\right] \mathrm{Ga}-14$, (blue), and $\left[{ }^{68} \mathrm{Ga}\right] \mathrm{Ga}-15$, (orange). (d) Plot showing the relative stability versus time of $\left[{ }^{68} \mathrm{Ga}\right] \mathrm{Ga}-14$ (purple) and $\left[{ }^{68} \mathrm{Ga}\right] \mathrm{Ga}-14 \supset \beta-\mathrm{CD}$ (blue) during incubation in human serum $\left(37^{\circ} \mathrm{C}, \mathrm{pH} 7.4\right)$. 


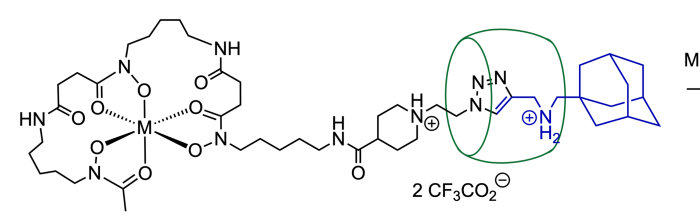

M-DFO-adamantyl-[2]semirotaxane (M-14)

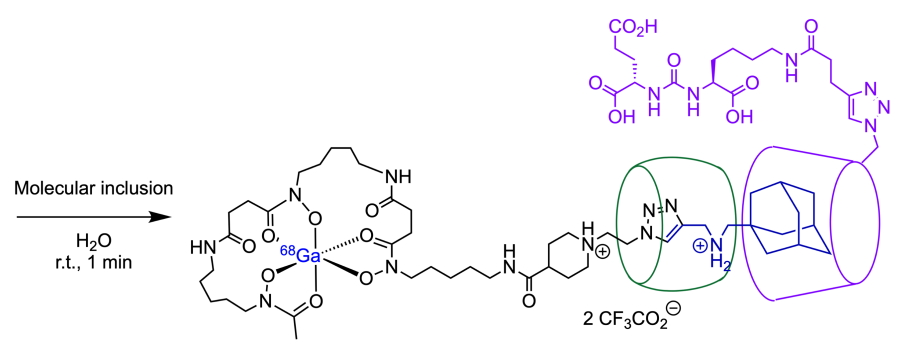

$\left[{ }^{68} \mathrm{Ga}\right] \mathrm{GaDFO}$-adamantyl-[3]semirotaxane ([68 Ga]Ga-14 つ 7)

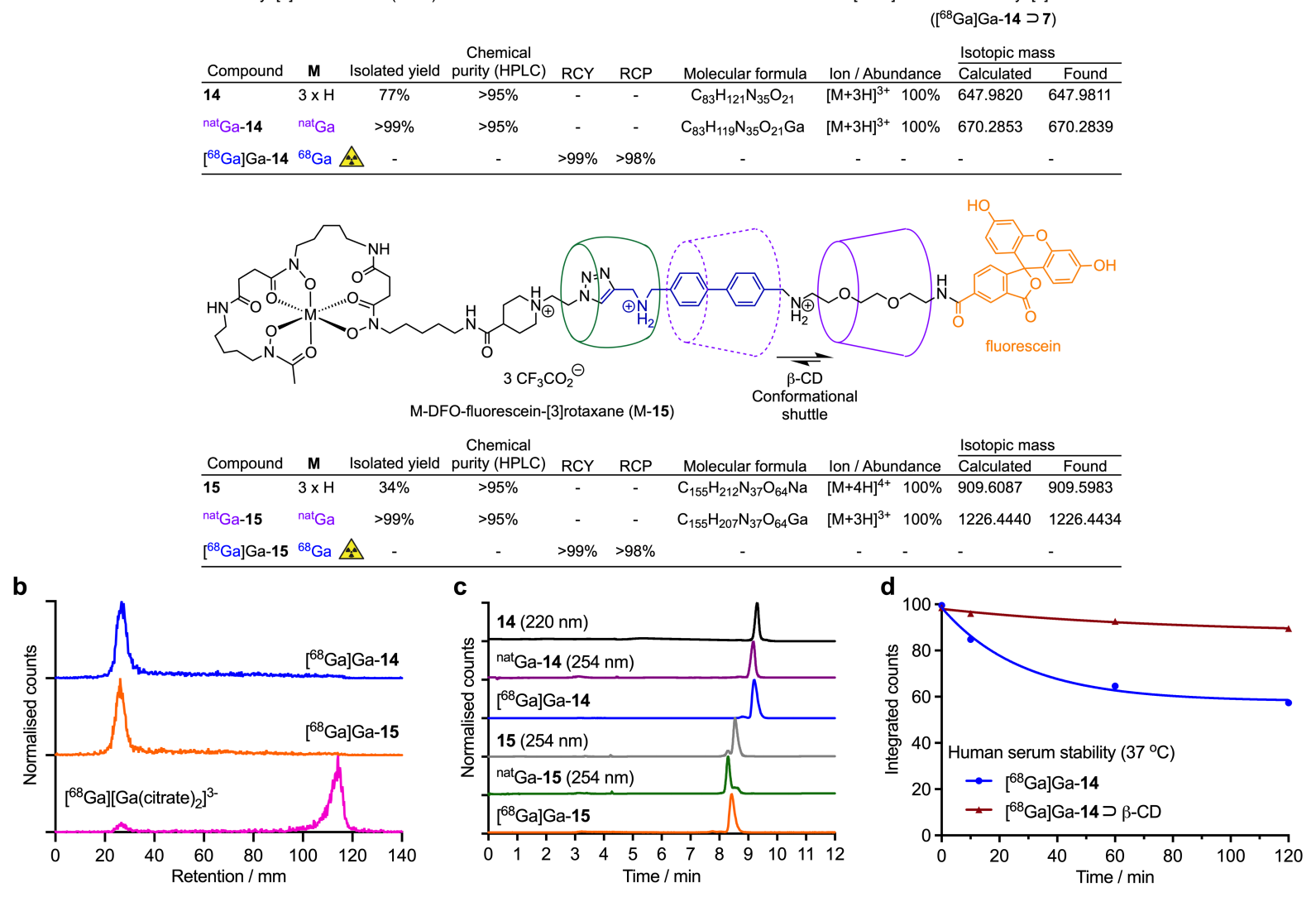

